Article

\title{
Lovely Ugly Bes! Animalistic Aspects in Ancient Egyptian Popular Religion ${ }^{\dagger}$
}

\author{
Branko F. van Oppen de Ruiter 1,2 \\ 1 Department of History, University of Groningen, 9712 EK Groningen, The Netherlands; \\ bvoppen@yahoo.com \\ 2 Formerly Allard Pierson Museum, University of Amsterdam, 1012 GC Amsterdam, The Netherlands \\ + Dedicated in friendship to Robert Steven Bianchi.
}

Received: 20 February 2020; Accepted: 14 April 2020; Published: 17 April 2020

check for updates

\begin{abstract}
The popular yet demonic guardian of ancient Egypt, Bes, combines dwarfish and leonine features, and embodies opposing traits such as a fierce and gentle demeanor, a hideous and comical appearance, serious and humorous roles, an animalistic and numinous nature. Drawing connections with similarly stunted figures, great and small cats, sacred cows, baboons, demonic monsters, universal gods and infant deities, this article will focus on the animalistic associations of the Bes figure to illustrate that this leonine dwarf encompassed a wider religious significance than apotropaic and regenerative functions alone. Bes was thought to come from afar but was always close; the leonine dwarf guarded the sun god Ra along the diurnal solar circuit; the figure protected pregnant women and newborn children; it was a dancer and musician; the figure belonged to the company of magical monsters of hybrid appearance as averter of evil and sword-wielding fighter. Exploring the human and animal, demonic and numinous aspects of this leonine dwarf will not only further our understanding of its nature and function, but also its significance and popularity.
\end{abstract}

Keywords: hybridity; dwarfs; animalism; demons; apotropaism; rejuvenation; fertility; popular religion; ancient Egypt

\section{The Leonine Dwarf}

Charmingly hideous Bes is a well-known figure of ancient Egyptian popular religion (Figure 1). Much has been written about his exact status and nature, his origin and his function-much less so about his significance, a subject that promises to elucidate his widespread popularity from the Eighteenth Dynasty onwards well into the Roman period. ${ }^{1}$ He is considered a grotesque demon, a deformed dwarf, a pygmy from far away, a fierce animal wielding his knife, a jolly dancing musician, a brave warrior fighting against the forces of evil, a guardian spirit of the household and family life within it, a New Kingdom addition to the Egyptian pantheon, a protective deity of all of Egypt worshipped throughout the Nile Valley since Pre-dynastic times, yet for whom no temples were built and no priests were installed. This friendly beast that charms while he repels, was he human or animal, demon or god?

Though this paper will not be able to address all categories equally, I will argue that Bes transcends definition by combining human and animal, demonic and numinous traits-and because of this multivalence was highly suitable for popular religious beliefs. Bes images are found in nearly every

1 From the vast literature on Bes, esp. see: RML s.v. 'Bes, Besa,' I: 2880-98 [Drexler]; RE s.v. 'Besas,' III:1 (1897), coll. 324-26 [Sethe]; Ballod (1913); Altenmüller (1965); Malaise (1987); Scheurleer (1987); Romano (1989); Meeks (1992); Dasen (1993, pp. 55-83); Hart (2005, pp. 49-50). 
archaeological context: from the private domestic sphere, via the royal funerary realm, to the religious temple domain. Yet, the evidence is predominantly iconographic. Little was written in antiquity about Bes. Apart from his own physical appearance, to compensate for this limited evidence, animals and deities will with whom Bes was closely associated will be reviewed, such as felines and primates, as well as Hathor and Ihy, Ptah and Sachmis, Bastis and Harpocrates, Thouëris and Tithoës. Their mythic and cultic ritual and religious roles will cast light on our Bes figure. An examination of animalistic aspects that Bes has in common with other beings will bring notable dualities to the fore that will help to illuminate this lovely ugly character. ${ }^{2}$ Additionally, it might be pertinent to add a note about the use of evidence from different periods. Without wising to ignore or deny diachronic transformations, the emphasis here is holistic-in an attempt to reveal the importance of the oft-neglected animalistic features of the Bes figure.

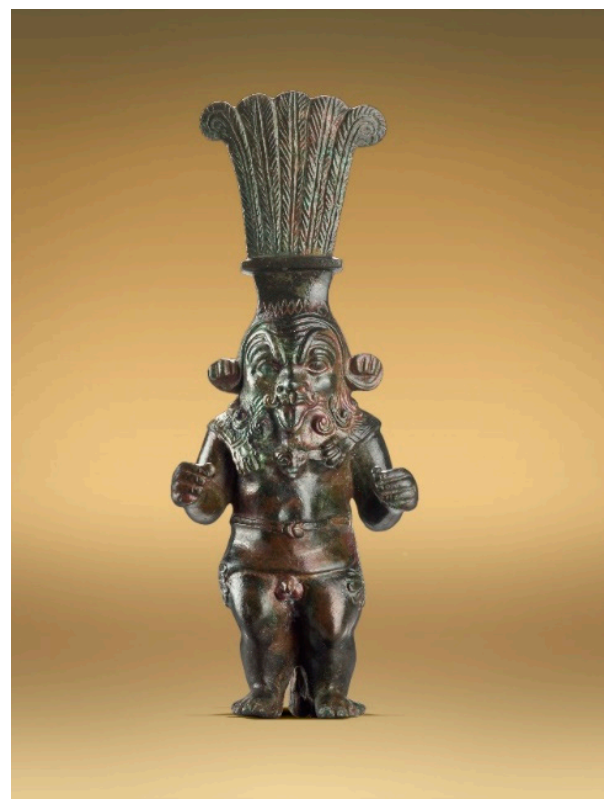

Figure 1. Standing Bes (FGA inv. no. ARCH-EG 620); bronze figurine; Egypt(?), ca. 4th-1st cent. вСЕ. [Photo by Grégory Maillot; image courtesy of Fondation Gandur pour l'Art, Geneva].

As scholars have long pointed out, the name of Bes is first attested only during the New Kingdom Eighteenth Dynasty ( $\mathrm{ca}$. 16th cent. вСЕ). ${ }^{3}$ Furthermore, the familiar image of the leonine dwarf with the mask-like grimace and tall-feathered crown likewise first appears only during this period. This combination of textual evidence and iconography does not necessarily mean that Bes was a relatively recent import into Egyptian religion, as earlier scholars-such as Erman, Six, and Petrie contended. ${ }^{4}$ It has to be remembered, however, that a measure of speculation is involved when trying to find Bes in the centuries preceding the New Kingdom.

Moreover, Bes only achieved widespread popularity in Egypt from the Late Period (since ca. $700 \mathrm{BCE}$ ) and even more so in Graeco-Roman times throughout the Mediterranean ( $c a$. 4th cent. BCE - 4th cent. CE). ${ }^{5}$ For, after the Third Intermediate Period, he can be found in homes, cemeteries, large temples of the great gods of Egypt-and in every conceivable material and medium (sculpture, furniture, jewelry,

2 A note on the transliteration of Egyptian names and terms: preference is given to Latinized spelling of personal and divine names, while Egyptological transcriptions are provided parenthetically; this preference is motivated by readibility for the general audience.

Meeks (1992); Takács (2002).

Erman (1882), esp. figs. 4-10; Six (1885, pp. 94-97); Petrie (1906, pp. 62-63).

Ballod (1913, pp. 61-70); Scheurleer (1987); Malaise (2010), p. 3 and n. 12 (with lit.). Romano (1989) does not cover the Graeco-Roman period. 
amulets, etc.). In the Ptolemaic period, or just before, the so-called Bes Chambers were constructed at Saqqara and birth chapels (mammisis) were built in several of the larger temple complexes (Figure 2). ${ }^{6}$ It is not until the Roman Imperial age that a temple may have been erected in honor of Bes himself-and then far from the chief political and religious centers, at Bawiti in the Bahariya oasis. ${ }^{7}$ (This does not take into consideration the so-called Tymphonium at Wad ben Naqa near Meroë in the Kingdom of Kush (mod. Sudan), which should best be understood as a temple of Mut and Amun.) ${ }^{8}$

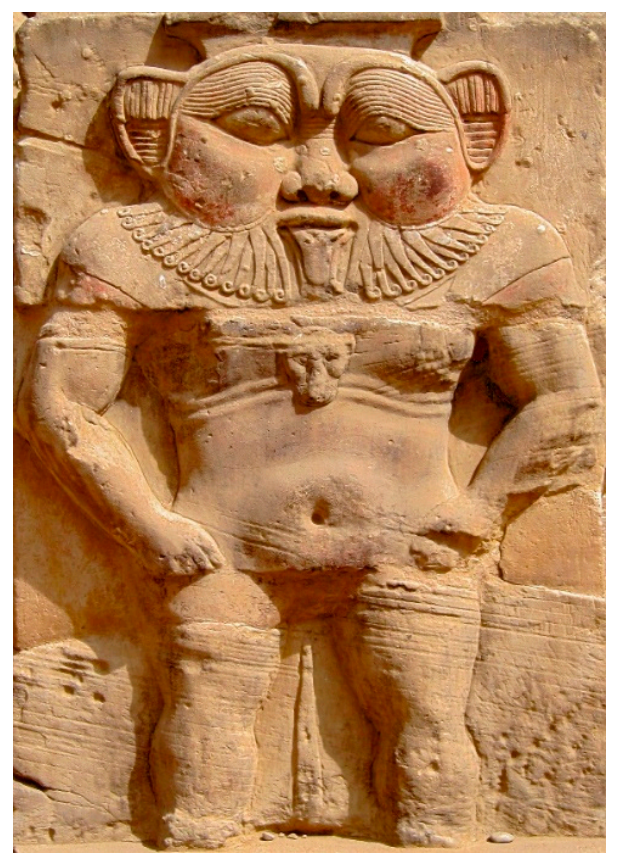

Figure 2. Standing Bes; relief scene; Dendera, Upper Egypt; ca. 1st-2nd cent. cE. [Photo by Olaf Tausch, Creative Commons].

Conversely, the great Bes savants of the previous century, such as Franz Ballod (1913), Hartwig Altenmüller (1965), and James Romano (1980, 1989), saw in Bes a native Egyptian creation, perhaps of highest antiquity-i.e., from the Pre-dynastic period or the Old Kingdom at the latest. They substantiate that suggestion with visual evidence reminiscent of the figure of Bes, but without textual corroboration. This evidence, for instance, includes an enigmatic, statuesque figure with grotesque facial traits, long hair or a lion's mane, and upright feline ears among ritualistic dancing dark-skinned boys and fair-skinned girls on a limestone tomb relief reportedly from Giza (Figure 3) and a near-contemporary fragmentary figure with leonine features and pendulous breasts on a relief scene of the mortuary temple of Sahura (Ś3hwr') at Abysir (north of Saqqara; Figure 4). ${ }^{10}$ This Fifth Dynasty pharaoh ( $f$. са. 2475 все), incidentally, also sent an expedition to the Land of Punt (about which more below). From the Middle Kingdom, representations of leonine figures become more abundant, particularly on the so-called magic knives or birth tusks-i.e., boomerang-shaped wands made of hippopotamus ivory with images of composite monsters of the realm of demons (Figure 5). ${ }^{11}$

\footnotetext{
Budde (2008); Volokhine (2010); Manniche (2015).

Hawass (2000).

Graves (2012); Onderka and Vrtal (2018).

BM inv. no. EA 994 (reg. no. 1879,1120.177); Romano (1989), cat. no. 3; Russmann (2001, p. 7).

ÄMGS inv. no. 2.095; Romano (1989), cat. no. 1.

Altenmüller (1965, esp. pp. 36-38); for the magic wands, or "birth tusks," now see: Quirke (2016).
} 


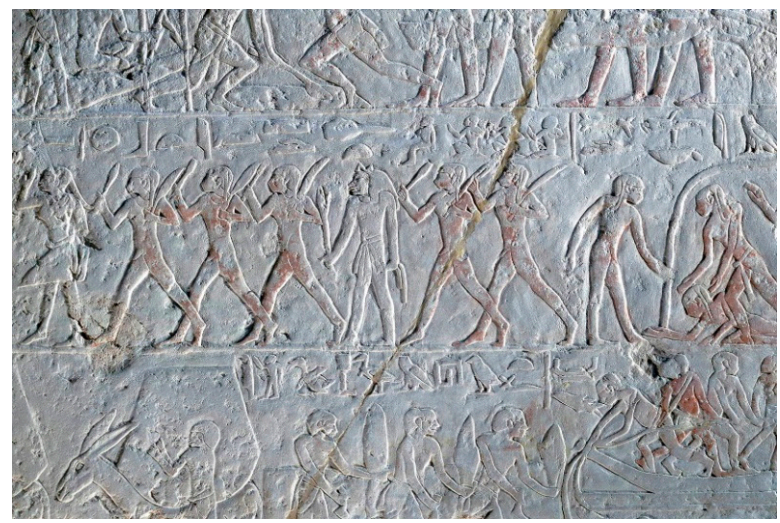

Figure 3. Ritual dance around a "Bes" figure (BM inv. no. EA 994; reg. no. 1879,1120.177); limestone relief; Giza, Lower Egypt; ca. 25th cent. всE. [Image courtesy of the Trustees of the British Museum, London].

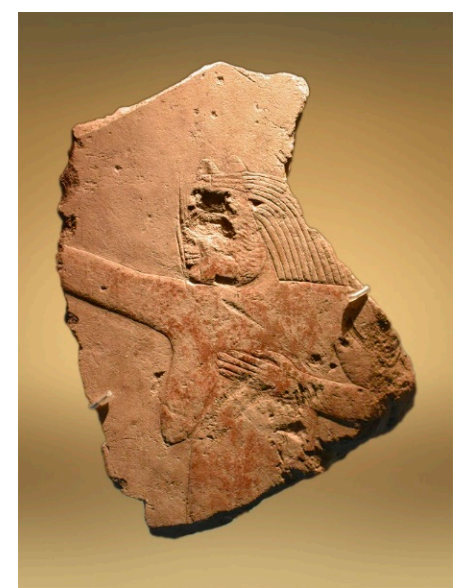

Figure 4. Leonine figure with pendulous breasts (ÄMGS inv. no. 2.095); limestone relief; Abysir, Lower Egypt; ca. 2500-2450 все. [Photo by the author; taken at the Allard Pierson Museum, Amsterdam].

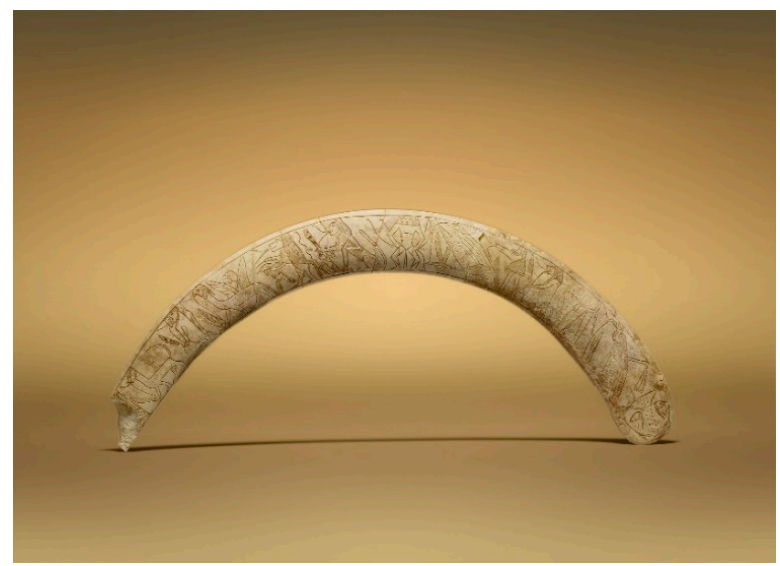

Figure 5. Magic wand (WAM acc. no. 71.510); hippopotamus ivory; Egypt; ca. 19th-18th cent. вСЕ. [Image courtesy of the Walters Art Museum, Baltimore].

Explanations of the meaning of the name associated with the familiar figure of Bes have thus far yielded little result. ${ }^{12}$ "Bes (Bś)" is rendered in hieroglyphs as $\int_{\uparrow}(b+s+$ det. $)$, but its etymology

12 Meeks (1992). 
remains uncertain: perhaps *Biśw (pronounced “Bisu”). The determinative $\uparrow$ (F27, "skin") might be taken to indicate that Bes was considered animal, as this determinative normally denotes mammals. Nineteenth-century scholars suggested that "bes" was the name of a feline of the Panthera genus, such as a lion, cheetah, lynx or leopard. ${ }^{13}$ This suggestion was based on a misunderstanding of $b_{3}$ św $\sqrt{\mathbb{N}} \neq$ as "panther" (instead of $b_{3}$ šm'). Other readings, which also remain unsatisfactory, include: "flame" from

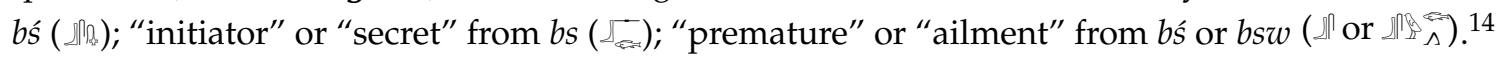

A pun on the foot sign $\_$(D58) in Bes' name is found in spell 125 of the Book of the Dead, where the deceased declares that "Bes-Ihy is the name of my right foot."15 Through a metathesis of $i b_{3} w$

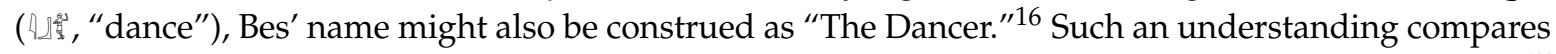
well with the name of a similar magical leonine dwarf, Aha ('h3), which means "The Fighter."17 Whatever the meaning of his name may have been, one should also remember that the hieroglyph in

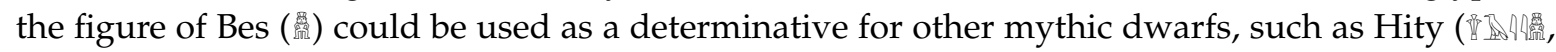
$\left.H_{3} t j\right)$. We will have opportunity to return to Aha, Hity and Ihy duly.

While the meaning of the name Bes thus offers no certain clues to his identity, the iconography of this familiar figure is not exactly hard and fast either. ${ }^{18}$ On the one hand, scholars give the name "Bes" to various types of mythic dwarfs, while similar-looking dwarfs are occasionally called by different names where written evidence is available. Perhaps, then, "Bes" should be considered a collective noun of Egyptian mythic dwarfs, rather than the name of a specific being. For that reason, scholars have opted for terms such as "Bes image," "Bes figure" or simply "Bes" within quotation marks, to refer to the leonine dwarf. So, although the Bes figure appears easily recognizable, it might be appropriate to summarize its main features before delving deeper into the significance of the iconography of the leonine dwarf.

Egyptian deities regularly wear crowns on their head as an attribute of identification. In the case of Bes figures that is often the case, too, namely a crown of several tall feathers (four or more) on a modius-type base. Bes shares this type of headdress with Anuqis, goddess of Elephantine, the island at the first cataract of the Nile on the Nubian border. The Bes figure, however, can also appear uncrowned or wear different types of headdresses.

Bes' facial features are perhaps the most recognizable - foremost the fact that the figure is frequently portrayed frontally, and only occasionally in full or half profile. The celestial bovine goddess Hathor is one of the few Egyptian deities whose face is also regularly depicted frontally, like the hieroglyph for "face" $(\mathrm{D} 2, \mathrm{hr}) .{ }^{19}$ Bes' face is habitually drawn into a bestial grimace, occasionally resembling that of a lion or baboon. His animalistic aspects are emphasized by his leonine mane and round ears. Bes also sports bushy eyebrows, a moustache and a beard, which are sometimes unwieldy and furry, at other times stylized in decorative swirls. Furthermore, he tends to have deep-set gawking eyes, a pudgy nose, and thick lips pulled into a teeth-baring grin with a protruding tongue. Sometimes these features render his appearance Nubian.

The familiar Bes figure has the stunted and rotund body of a dwarf. His torso may be muscular with a delineated ribcage, but more often he shows off a potbelly and sometimes even pendulous breasts. His arms are either akimbo with his hands on his hips, or he holds attributes such as serpents, weapons or musical instruments in his hands. In some instances, Bes is depicted with one or two pairs of feathered wings. His rump is usually pronounced and sports a feline tail, sometimes with a tuft.

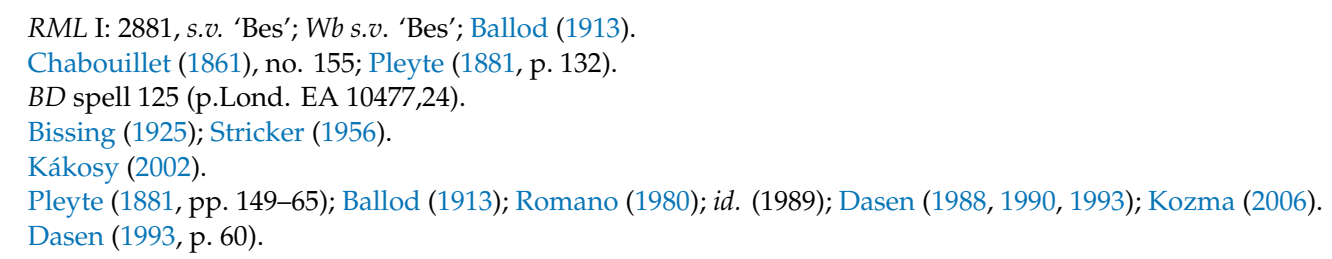


Normally his penis is small and as a rule circumcised, but very rarely he is portrayed with an enormous phallus. His bandy legs are generally short and thick, with his feet at times pointing outward.

Bes figures are mostly nude, but he may also be seen with a loin cloth or kilt. Quite commonly he wears a leopard's skin over his shoulders, with the cat's head and forelegs hanging on his chest. The leopard's head over his chest is rather reminiscent of a gorgoneum, the apotropaic head of Medusa. Bes may also don a belt tied into a reef knot-i.e., the knot of Heracles (nodo herculis), associated with healing. ${ }^{20}$ Attributes related to figure include: scepters or weapons (such as a short sword or knife, mace or club); musical instruments (such as the lyre or lute, tambourine or cymbal, rattle or double flute); amulets (such as the $u d j a t$ or anch-sign); and plants (such as lotus or papyrus). In Graeco-Roman times, the warrior image of Bes adopts a breastplate and leather-strapped kilt, as well as an oval Galatian or round Roman shield.

Some of the oldest leonine figurines, which date to the Eleventh or Twelfth Dynasty of the Middle Kingdom ( $c$ a. 20th-19th cent. BCE), are actually female. They show a nude human body with a feline head, pendulous breasts, marked pudenda, and a cat's tail. Although they come without inscription, scholars call her Besa or Beset (Bś.t), the female form of Bes-and his female companion (Figure 6). ${ }^{21}$ In Graeco-Roman times, her representation is normally fully human, but recognizable by her tall-feathered crown and full round face (Figure 7). She may be partially or fully dressed and hold similar attributes to her male partner. Before the Hellenistic period, however, Bes was more often shown together with Thouëris than with Besa. They appear, for instance, on furniture from the tomb of Yuya and Thuyu, the parents of Tiye (and thus the maternal grandparents of Achenaton and great-grandparents of Tutanchamun). ${ }^{22}$

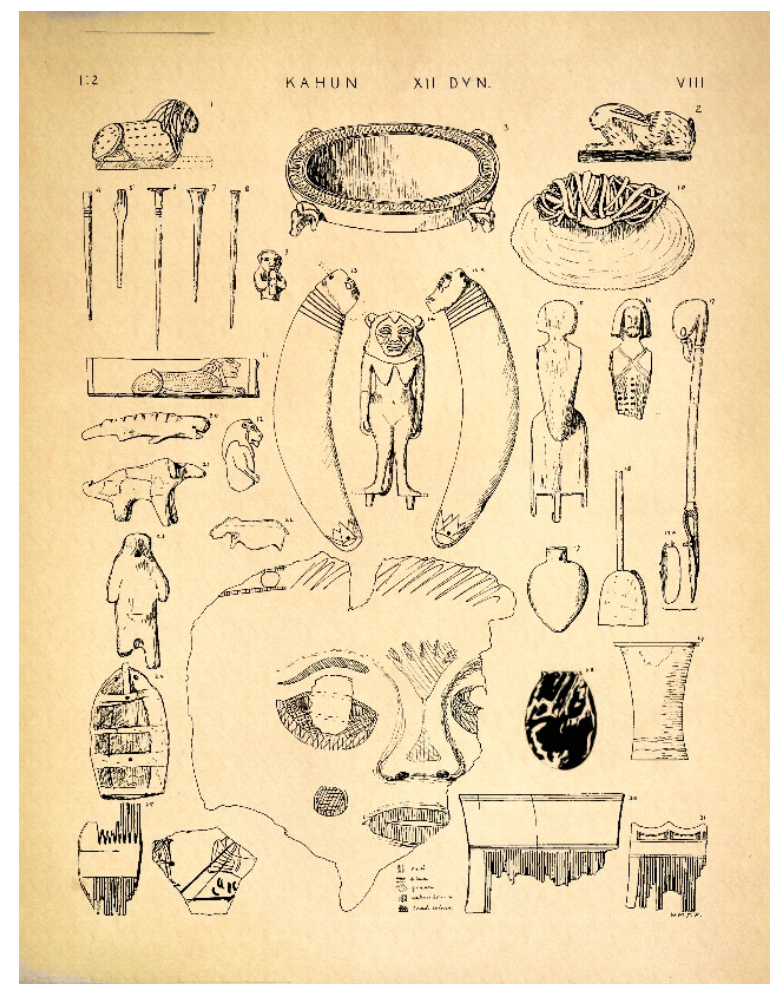

Figure 6. Besa and Ritual Artefacts-from W. M. Flinders Petrie, Kahun, Gurob, and Hawara (London, 1890), pl. 8. [Image courtesy of Cornell University Library, Ithaca].

20 Plin. Nat.Hist. 28.17.

21 Ballet (2012).

22 EMC inv. no. CG 51.110; Romano (1989), cat. no. 87; Fink (2011). 


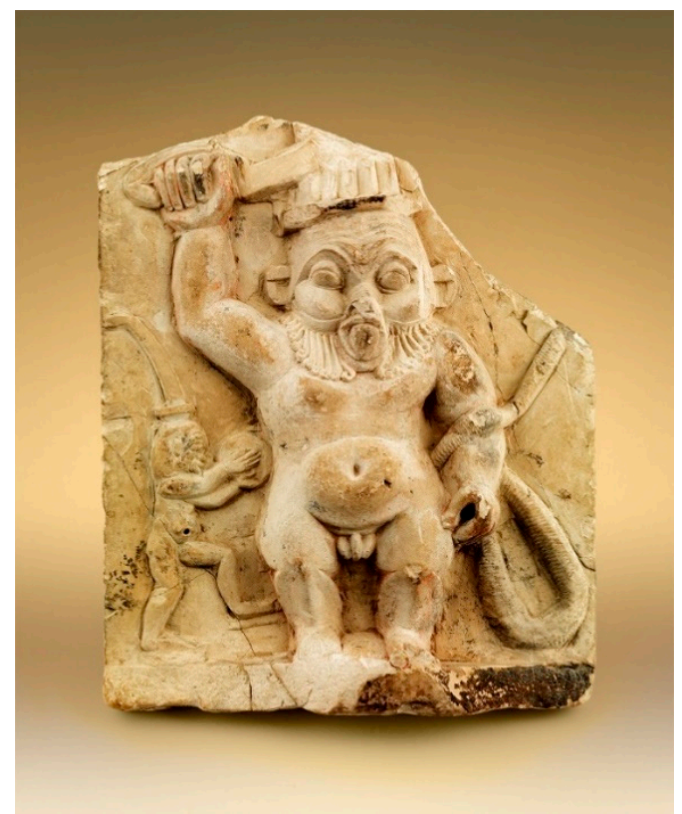

Figure 7. Bes and Besa (APM inv. no. 7947); limestone relief; Egypt; ca. 6th-2nd cent. всE. [Photo by Stephan van der Linden; image courtesy of the Allard Pierson Museum, Amsterdam].

\section{Dwarfs and Pygmies}

In Pharaonic representations, figures of divine, royal or noble status were habitually depicted as physically perfect. Still, historical dwarfs were shown in diminutive stature (hw', "short") without evident prejudice. Court official Seneb, for instance, was supervisor of linen weaving during the time of the Great Pyramids (ca. 2525 bce) and was portrayed with his wife and two children in his tomb at Giza. ${ }^{23}$ Seneb's short proportions are rather emphasized by the composition of the sculptural family group.

The dysmorphic image of Bes brings him close to the deformed street-types who became a popular theme in Graeco-Roman bronze and terracotta figurines (Figure 8). ${ }^{24}$ The familiar grimacing, stunted figure of Bes should be understood as a growth disorder (i.e., achondroplasia; $n m w$, "dwarf," the term commonly used for the Bes image). In a New Kingdom magic spell, it is said of a mythic dwarf (nmw) that "his face is big ('3), his back is long $\left(k_{3}\right)$, his legs are short $\left(h w^{\prime}\right) . " 25$

Malformed street types and dwarfs are to be distinguished from the stunted figures of the Pygmies $\left(d_{3} n g\right)$, whose stature is not due to a birth defect. From the Old Kingdom, at least since the reign of Pepy II (ca. 2278-2184 bce), Pygmies of equatorial Africa were famed as dancers and imported via the lands of Yam (Sudan?) or Punt (Nubia?) from the "Land of the Horizon Dwellers (3htiw)" (Arabia?). ${ }^{26}$ Although the Bes figure does not seem to resemble a Pygmy, there will be occasion to return to the lands south of Egypt in connection with lions and baboons, dwarfs and dancers, Hathor and Hatshepsut.

\footnotetext{
EMC inv. no. JE 51.280; Dasen (1993, pp. 35, 127-30, pl. 28, fig. 2).

Volokhine (2010).

p.Mag.Harr. sp. U 8.9; Dasen (1993, p. 30).

Pleyte (1881, pp. 166-69); Stricker (1956); Graves (2012).
} 


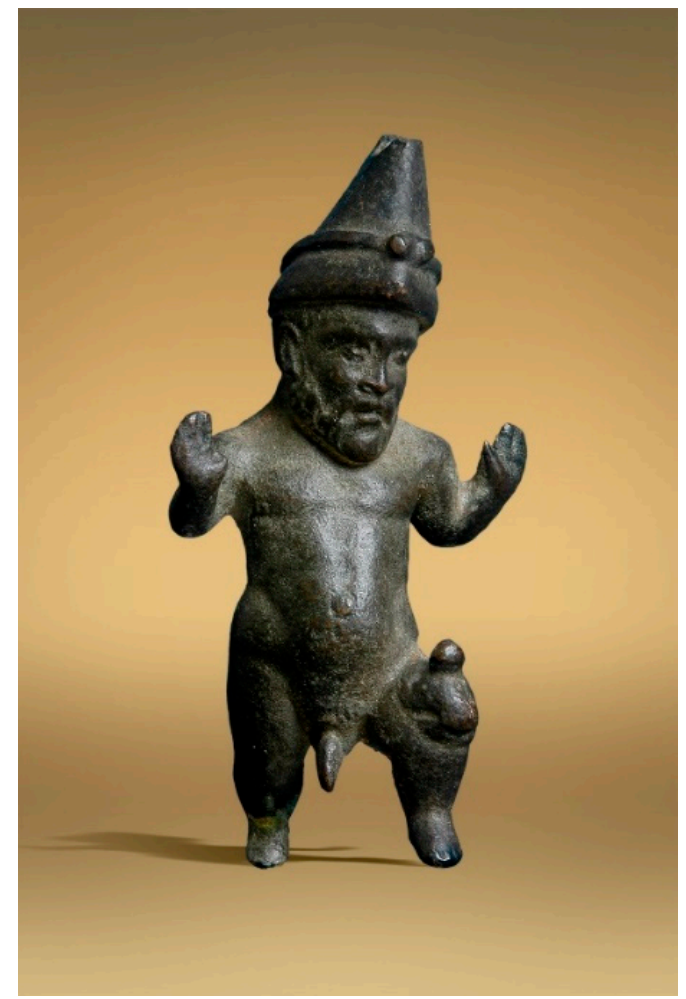

Figure 8. Surprised dwarf with toad on his knee (APM inv. no. 7982); bronze figurine; Egypt; 3rd cent. вСе. [Photo by Michiel Bootsman; image courtesy of the Allard Pierson Museum].

The oldest name attested for a leonine figure similar to Bes is actually that of Aha ( $1 h_{3}$, the "Fighter"; Figure 9). ${ }^{27}$ His name appears on magical wands in boomerang shape made of hippopotamus ivory, the earliest of which are dated to the time of the Sesostrids of the Twelfth Dynasty (ca. 1900 bce). ${ }^{28}$ This Middle Kingdom leonine demon shares with Bes the frontal depiction, as well as the mane, round ears, bandy legs and tail. Aha is habitually shown either strangling undulating serpents or brandishing knives; sometimes, he has feathered wings. He was believed to be the guardian of night, the protector of women and children, and the lord of dance and music. There is evidence, furthermore, that masked priests performed the role of Aha during the royal jubilee ceremony known as the Sed-festival $\left(h_{3} b\right.$-śd). This royal festival enacted the ritual rejuvenation of the Pharaoh's kingship. ${ }^{29}$

In this context, it might be appropriate to point out that at Sais, from the Late Period onwards, a dwarf god was worshipped as son of Neith, the terrifying goddess of warfare. ${ }^{30}$ The Greeks identified Neith with their goddess of warfare and crafts, Athena. ${ }^{31}$ Véronique Dasen suggests that the affiliation of this unnamed mythic dwarf with Neith was due to the warrior imagery, similar to that of Aha and Bes, which "aimed to repel malignant forces."32

According to Herodotus, the Memphite god Ptah, who he identified with Hephaestus, was worshipped in the likeness of a dwarf..$^{33}$ He further relates that the image of this dwarfish Ptah

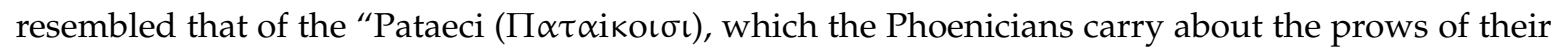

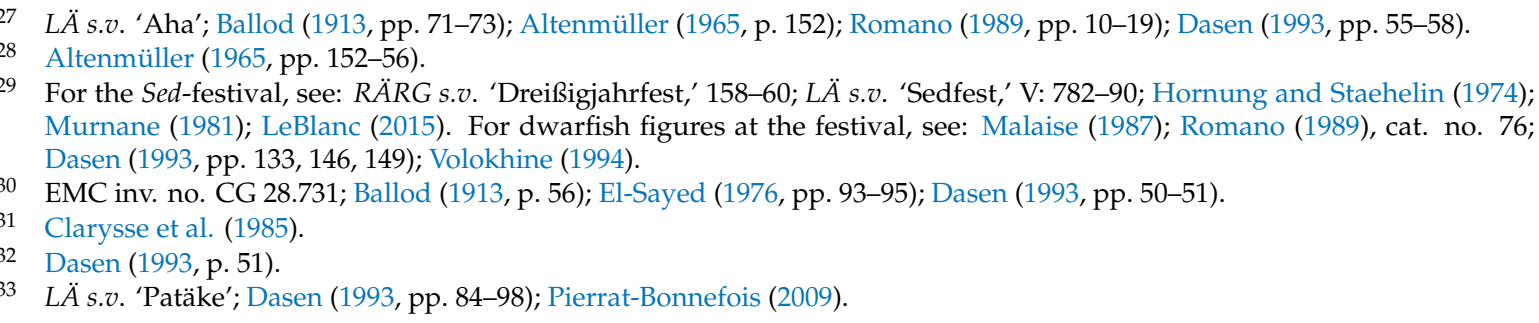


triremes." ${ }^{\prime 34}$ It may not be impossible that Herodotus had seen images of Bes in or near Memphis: a close connection was felt between Bes and Apis, the bovine manifestation of Ptah. The identity of these Phoenician dwarfs, at any rate, has thus far remained a mystery; nor are there any known Egyptian textual attestations identifying mythic dwarfs as a form of Ptah. In modern scholarly literature, nevertheless, the supposedly diminutive name "Pataecus (Pataikos)" is given to fully human dwarf figures that appear at least since the late New Kingdom as amulets. ${ }^{35}$ They were connected with the protection of children from evil. These amulets show a bald and nude dwarf, at times with a scarab as the top of his cranium, whose features conflate those of an infant and an elderly man. This conflation can be understood as expressing rejuvenation and rebirth. Another iconographical type displays the Pataecus figure as Master of Animals, strangling snakes or wielding knives, and standing atop crocodiles (Figure 10).

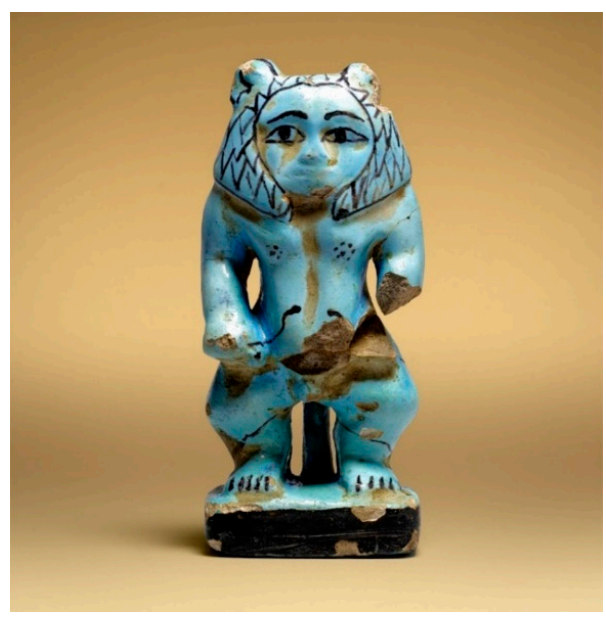

Figure 9. Standing Aha clutching serpents (WAM acc. no. 48.420); faience figurine; Western Thebes, Upper Egypt; ca. 1800-1750 все. [Image courtesy of the Walters Art Museum, Baltimore].

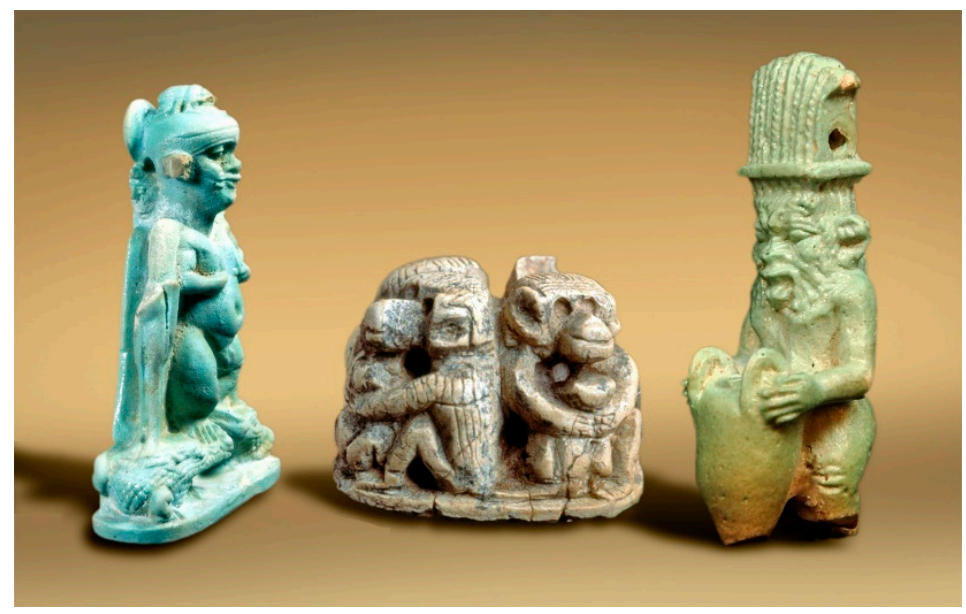

Figure 10. Amulets of Pataecus, baboons with babies, and Bes with amphora (APM inv. nos. 8925, 15.339 and 7683); (left) faience amulet; Egypt; са. 7th-4th cent. всЕ; (middle) ivory seal stamp; Egypt; Old Kingdom; (right) faience amulet; Egypt; ca. $3^{\text {rd }}$ cent. всE. [Photos by Michiel Bootsman; images courtesy of the Allard Pierson Museum].

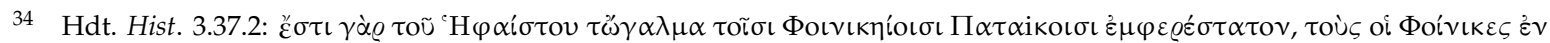

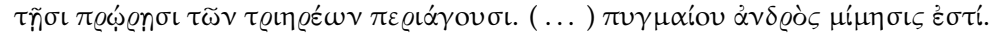

35 Hückel (1934); Andrews (1994, p. 39, fig. 36); Konrad (2007). 


\section{Fierce and Gentle Cats}

With its feline features-the lion's mane, round ears, tufted tail and spotted leopard's skin-the iconography of dwarfish Bes combines theriomorphic and anthropomorphic aspects. Egyptian deities are often of composite nature. Normally, however, their bimorphic appearance consists of an animal head on a human figure that embodies a physical ideal. Their figures are slim, healthy and clothed. The late Egyptologist James Romano argued that the Bes image derived from the upright rearing lion, which developed into a lion-man, who only subsequently acquired his dwarfish physique (Figure 11). ${ }^{36}$

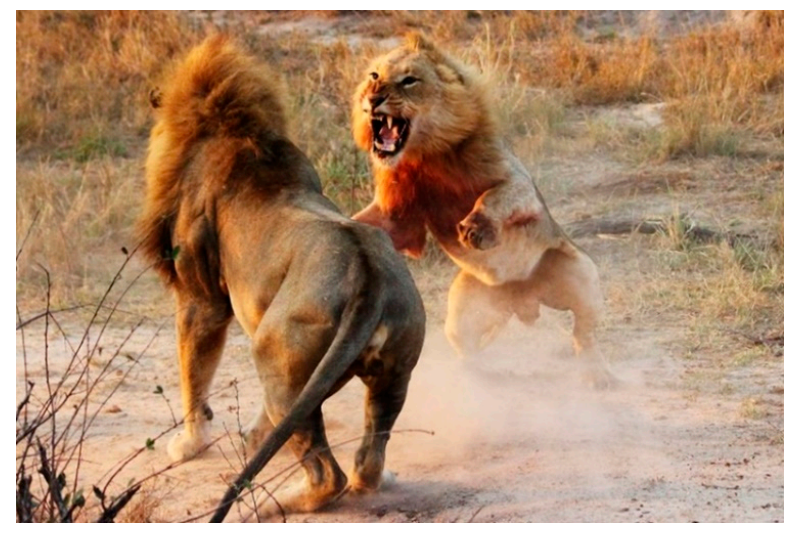

Figure 11. Upright lion attacking another. [Photo by Justin Glanvill, Barcroft Media].

Both lions and dwarfs, like baboons, could be depicted in Egyptian scenes guarding the rising and setting of the sun. ${ }^{37}$ They were thought to protect the solar journey through the sky. The sun god Ra himself was called the "dwarf of the sky" between heaven and earth, the "pillar" between the sky and the underworld. ${ }^{38}$ In the emanation of a great cat, Ra can be seen in underworld scenes slaying Apophis (' $3 p p$ ), the evil serpent, the demonic Lord of Chaos (Isfet) and enemy of truth and justice $\left(M a^{\prime} a t\right)$ (Figure 12). The image thus combines feline aspects, including the wielding of a knife, in a religious solar context.

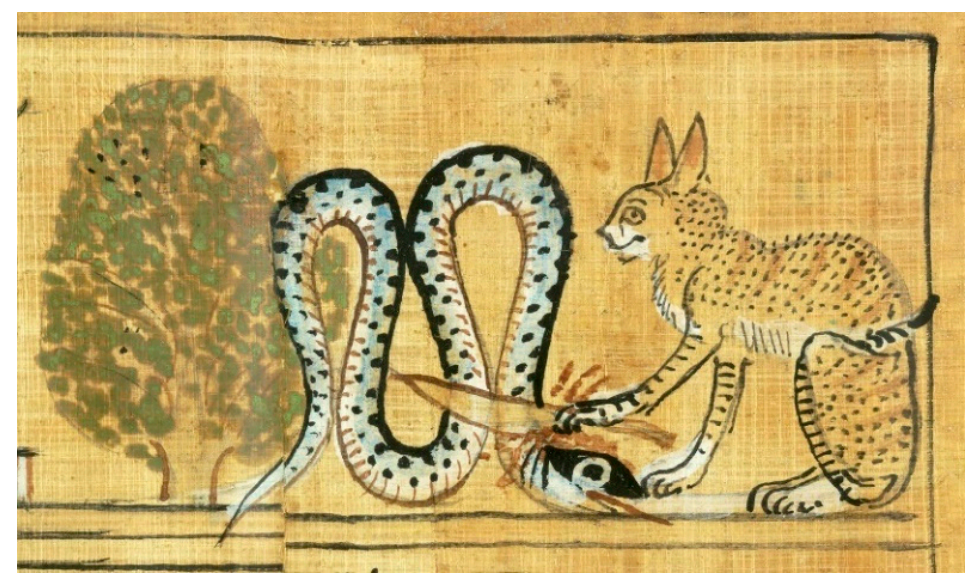

Figure 12. Apophis slain, from the Papyrus of Hunefer (BM inv. no. EA 9901,8); painted papyrus (detail); Egypt; ca. 13th-12th cent. все. [Image courtesy of the Trustees of the British Museum, London].

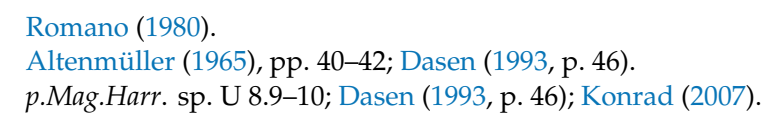


On a Late-Period wooden sarcophagus from Crocodilopolis, a unique scene shows Bes in place of the primordial god Shu supporting the arching body of the sky goddess Nut. ${ }^{39}$ The silhouette of this figure with upraised arms and legs astride could be assimilated with the image of the scarab-beetle god Chepri (Hprj, the "One Who Comes into Being"), the divine manifestation of the sunrise. ${ }^{40}$ While the Bes figure was not associated directly with Ra, lions and dwarfs were considered solar guardians. ${ }^{41}$ Like Chepri, Bes thus acquired regenerative significance, symbolizing birth and rebirth. ${ }^{42}$

In order to elucidate the significance of Bes' leonine aspects, it may prove beneficial to further explore some feline associations in ancient Egyptian religion-begging for the readers' patience while indulging these associations. For it should hardly be coincidence that the fierce goddess Sachmis (Śhm.t, Sechmet, the "Powerful") was depicted as a great lioness (Figure 13). ${ }^{43}$ This powerful goddess held sway over warfare as well as healing - an important combination of powers in the realm of domestic magic connected with the ivory wands and amulets showing Aha or Bes. She was the wife of Ptah and the daughter of the sun god Ra or Horus. Her son Nefertem (Nfr-tm) was at times represented with the head of a lion-e.g., in the Nefertem Chapel of the Temple of Seti (Sethos) I at Abydos. ${ }^{44}$ His attribute was the sacred blue lotus (Nymphaea caerulea), which opens in the morning as the sun emerges from the horizon-thus re-enacting creation.

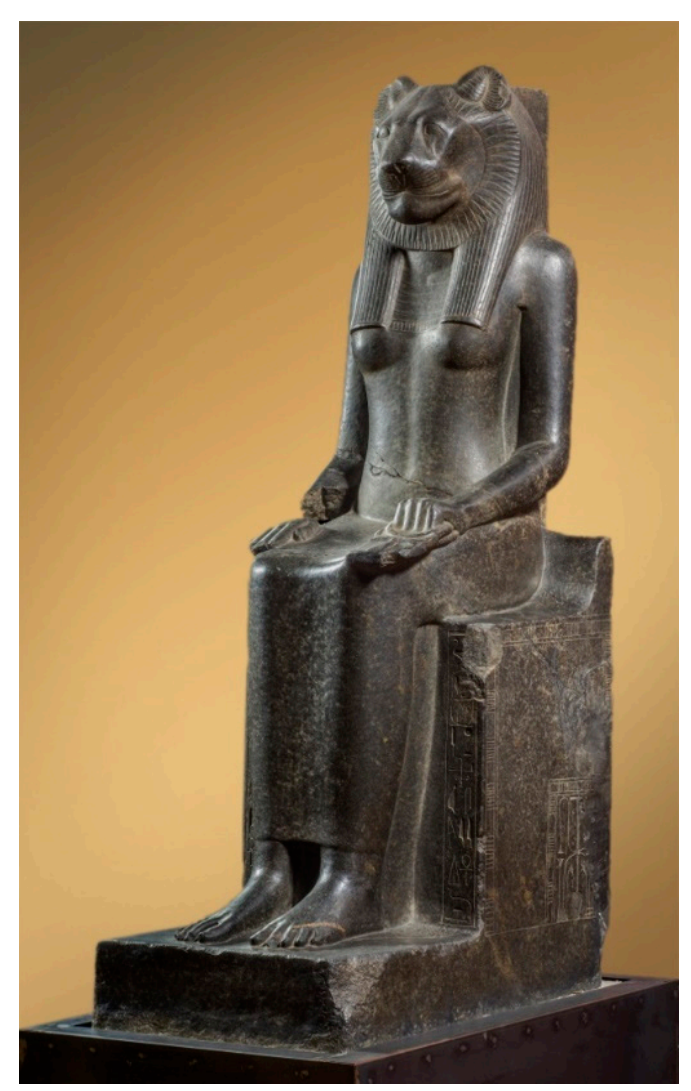

Figure 13. Enthroned Sachmis (EMT inv. no. C.245); granodiorite statue; Thebes, Upper Egypt; ca. 1390-1353 все. [Image courtesy of the Egyptian Museum, Turin].

\footnotetext{
39 Petrie (1889, p. 9, §13, pl. 2).

40 Dasen (1993, p. 50).

41 Malaise (1990).

42 Cf. RMO inv. no. AMS 26A/7: spell 12.6 to be spoken "four times over a dwarf of clay placed on the brow of a woman who is giving birth while suffering"; Borghouts (1971, p. 29, pl. 14); Töpfer (2014).

43 Altenmüller (1965, pp. 144-46).

44 RÄRG s.v. 'Nefertem'; L ̈̈ s.v. 'Nefertem'; Mariette (1869), I: 23 § 81, pl. 38c; Cooney (1954, pp. 23, 26-27); Hart (2005, p. 99).
} 


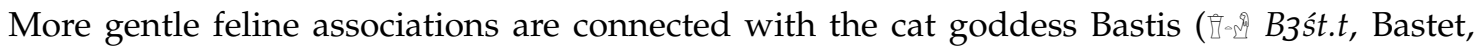
"She of the Ointment Jar"? Figure 14). Whether or not her name derives from the alabaster ointment jar with which her name was written, perfumes, unguents and cosmetics were linked with Bastis. She protected the birth and growth of children and was a guardian against disease and evil, much like Bes. Like Sachmis, she was goddess of warfare, and, like Hathor, her attributes included a rattle (sistrum, sśhm) and a protective beaded necklace (menat, mni.t). The Greeks identified Bastis with Artemis, the Mistress of Animals, goddess of hunting and childbirth, and protectress of wilderness and young girls. Since the time of the New Kingdom, leonine Miysis ( $M_{3}{ }^{\prime} h{ }^{\prime}, \mathrm{Ma}^{\prime}$ ahes), who slays serpents with his knife just like Ra, Aha and Bes, emerged as the son of Bastis or Sachmis—and is at times a double for Nefertem.

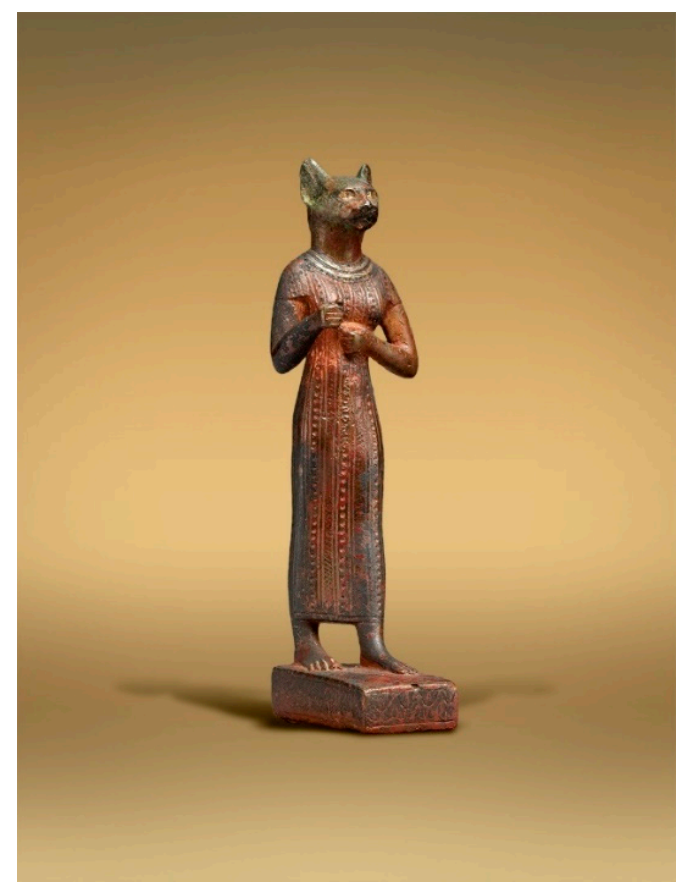

Figure 14. Standing Bastis (MMA acc. no. 34.6.1); bronze figurine; Egypt; ca. 7th-1st cent. всE. [Image courtesy of the Metropolitan Museum of Art, New York].

The fierceness of the lioness Sachmis (Sechmet) and the gentleness of the feline Bastis (Bastet) combine in — and may ultimately derive from—the primordial goddess Tefnis (Tf-nt, Tefnut), consort of Shu (Figure 15). ${ }^{45}$ Together, Shu and Tefnis, son and daughter of the creator god Atum-Ra, cosmic parents of Geb and Nut (Earth and Sky), represent principles of duality such as sun and moon, east and west, day and night, light and dark, dry and wet, right and left, male and female. Through a series of associations, Tefnis became the solar eye (udjat), the upright cobra (uraeus), Mistress of the Flame, and great lioness. In the Myth of the Solar Eye, a wrathful Tefnis has abandoned her father, leaving Egypt to dwell in far-off lands to the south (Nubia). ${ }^{46}$ Shu and Thoth disguised themselves as monkeys to fetch her and re-join her with Atum-Ra and the other gods of Egypt, which caused great rejoicing. At Philae, it was said that "Tefnut is furious as Sechmet and friendly as Bastet." 47 The importance of the relation of monkeys and lions with far-off Nubia for Bes will be soon made clear.

45 LÄ s.v. 'Tefnut'; Preys (2006); Jackson (2018).

46 RÄRG s.v. 'Sonnenauge' and 'Tefnut'; LÄ s.v. 'Hathor' and 'Tefnut'; Junker (1911); Spiegelberg (1917); Altenmüller (1965, pp. 82-86); Daumas (1968); Pinch (1993, pp. 191-97).

47 Junker (1911, p. 32). 


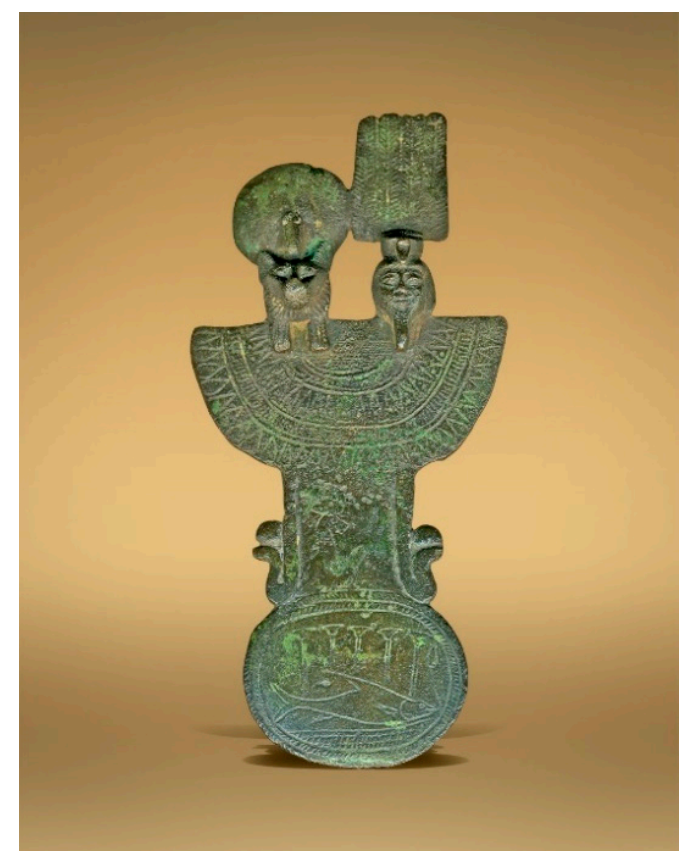

Figure 15. Menat with Shu and Tefnis (WAM acc. no. 54.1515); bronze artefact; Egypt; ca. 7th-4th cent. все. [Image courtesy of the Walters Art Museum, Baltimore].

\section{Drunken Cows and Dancing Monkeys}

The Myth of the Solar Eye brings us to the Great Celestial Cow Hathor. For it was said that Tefnis became as lovely as Hathor upon her return to Egypt; and, like Tefnis, Hathor could be both vengeful and gracious. When the sun god Atum-Ra wished to destroy mankind, he sent Hathor-yet, when he felt remorse over the carnage she caused, he flooded the land with beer stained with the juice of pomegranate, to quench her blood lust and trick her into a drunken stupor. Ever since, the goddess' anger had to be placated with beer and wine, dance and music, and the ritual shaking of the sistrum ( $(i)$ and the menat ( $(0)$ ). From the feline associations of Bes with Ra, Sachmis, Bastis, and Tefnis, we have thus arrived at his connections with bovine elements. At Dendera (Tentyris), "Land of the Two Uraei," Bes was indeed considered a companion of the sky goddess Hathor. ${ }^{48}$

Apart from solar symbolism, Bes shared many other aspects with Hathor, too-aspects that substantiate the significance of their companionship (Figure 16). Like Hathor, Bes was fierce as well as gentle: as warrior wielding his knife or sword he was merciless; but he also played an important festive role as dancer and musician, was connected to beer and wine, ${ }^{49}$ and protected love and sexuality. His presence in the birth chapels (mammisis) at the Ptolemaic and Roman Imperial Egyptian sanctuaries, especially that at Dendera-Hathor's chief center of worship-further illustrates his importance for childbirth, both divine and royal. Bes and Hathor were both regularly depicted frontally-in contrast to the conventional profile representation of Egyptian deities and human figures. Their heads frequently decorated the capitals of temple columns and other architectonical monuments. The same decorative element occurs on instruments such as rattles and cosmetic attributes such as mirrors.

48 Pinch (1993, pp. 290-94); Dasen (1993, esp. 79-80); Hart (2005, p. 50).

49 For wine cups, beakers, flasks and vases connected with Bes: Athen. Deip. 11.28 §784в ( $\beta \tilde{n} \sigma \sigma \alpha)$; Poll. Onom. $6 \S 69$ ( $\beta \eta \sigma \iota \alpha \kappa o ́ v) ; c f$. Hedylus (apud Athen. 11.97 §497D: rhyton in the shape of Bes made by Ctesibius for Arsinoe Zephyritis). 


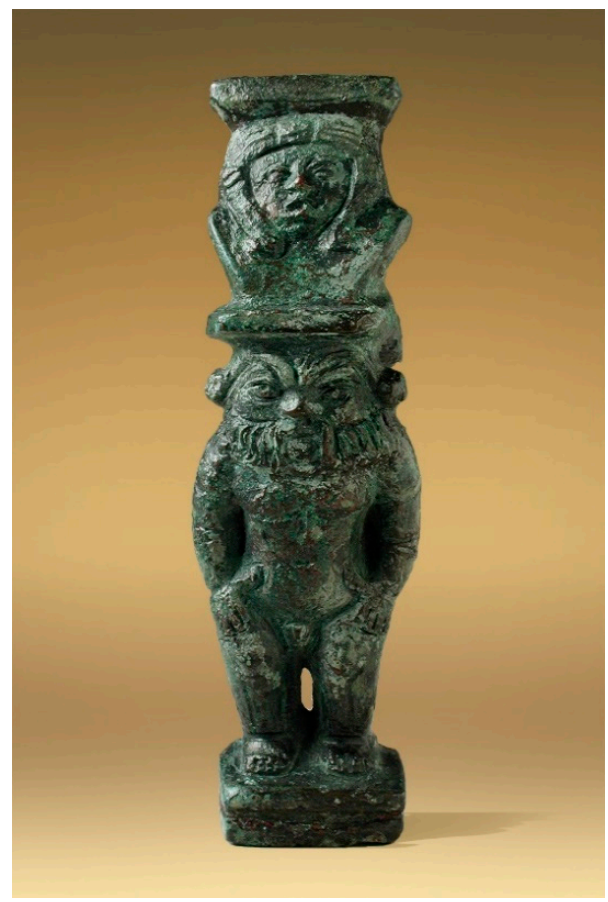

Figure 16. Bes with Hathor capital (LACMA inv. no. M 80.198.12); bronze figurine; Egypt; ca. 4th-1st cent. всE. [Image courtesy of the Los Angeles County Museum, L.A., California].

In scenes at the temple complex of Dendera, dancing leonine dwarfs appear that are indistinguishable from each other, determined by the same sign (㕻) and moreover in plural (i) with the names Bes and Hity ( $\left(h_{3} t^{i}\right)$, " just as Aha derives from "fighting" and Bes maybe comes from "dancing." It might also be possible, though, that Hity emerged in the Late Period as a subsequent linguistic development of Aha (from ' $h_{3}$ via ' $h_{3} w t i$ to $\left.h_{3} t i\right)^{51}$ Much like Aha and Bes, Hity was represented as dancer and musician. Bes could additionally be identified with the rattle shaker Ihy (I\$n IIhy, the "Musician"), son of Hathor and Horus (Figure 17).

While Hathor-Tefnis was said to have returned from afar, epithets also proclaimed that Bes hailed from distant lands..$^{52}$ One of his titles was "Who Comes from the Land of the Gods $\left(T_{3}-N \underline{t r}\right)$. " The location of this mystical region might correspond to the southern area of the Red Sea coast, where-from an Egyptian perspective-Atum-Ra emerged at dawn. Several earlier scholars, such as Brugsch, Erman and Maspero, therefore believed that Bes was originally an Arabian or even Near Eastern god..$^{53}$

On the Roman birth chapel (mammisi) at Dendera, dating to the reign of Hadrian (r. 117-138 CE), he was, however, also called the "Lord of the Land of Punt," 54 a country connected with Nubia or the African side of the Rea Sea coast (mod. Sudan, Eritrea or Ethiopia) - perhaps even as far south as the Horn of Africa (mod. Somalia). Some scholars, including Sethe, Wolff and Delpech-Laborie, have for that reason argued for an equatorial origin of Bes. ${ }^{55}$ Nubia and the Red Sea coast were, naturally, also the regions from which Egyptians acquired lions and baboons, as well as dwarfs.

\footnotetext{
LÄ s.v. 'Hit'; Ballod (1913, pp. 11-14 and 24-36); Romano (1989, p. 13 n. 49); Dasen (1993, pp. 55-56). 


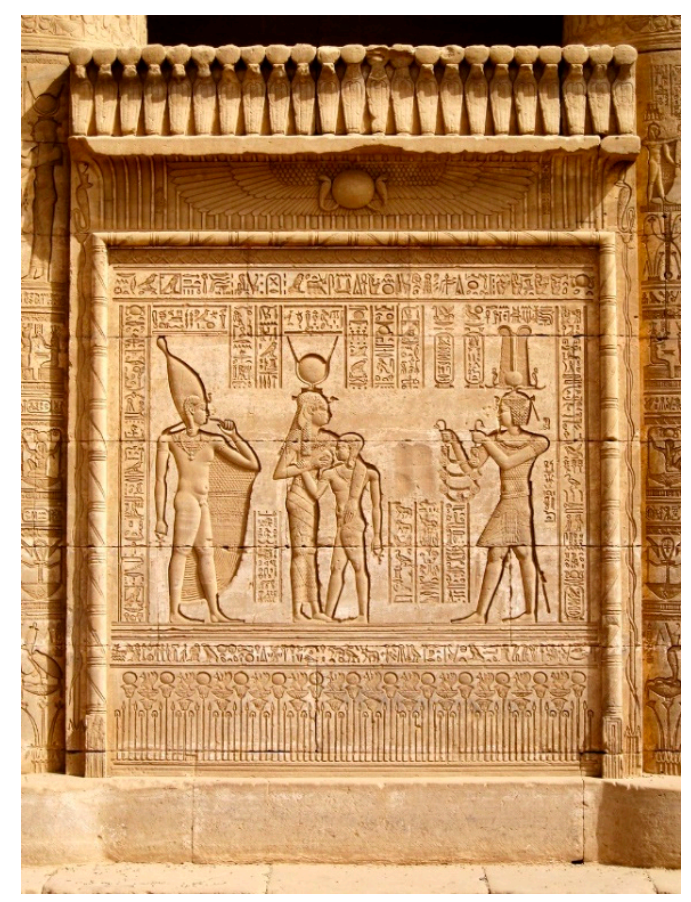

Figure 17. Hathor and Ihy (Roman Birth House); relief scene; Dendera, Upper Egypt; reign of Trajan (68-117 CE). [Photo by Olaf Tausch, Creative Commons].

In this context, it might be worthwhile pointing out that Queen Hatshepsut (ca. 1473-1458 bce)

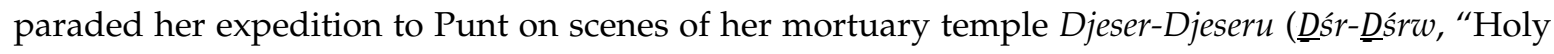
of Holies") on the west bank of the Nile, opposite Thebes (mod. Luxor). Among the reliefs in the colonnade along the ramp to the third level are scenes of the remarkably obese and dwarfish Queen Ati, the wife of King Perahu of Punt (Figure 18). ${ }^{56}$ On the other, southern, side of the ramp is a colonnade depicting the divine birth of the princess surrounded by guardian deities and protective genies (Figure 19). Under the bench are Bes and Thouëris, the only two beings whose monstrous bodies deviate from the ideal physique exemplified by Hatshepsut and the perfect gods around her. In this respect, Bes and Thouëris appear to parallel Queen Ati in the Punt colonnade on the northern side. ${ }^{57}$

The Nubian nature of Bes might additionally have been expressed by the tall feathers of his headdress. The same feathered crown was the attribute of Anuqis ("nkt, Anuket, the "Embracer"), the Elephantine goddess of the Nile and the river's inundation (Figure 20). While the Greeks equated Anuqis with Hestia, the Romans recognized Vesta in her. ${ }^{58}$ Whether Bes originally-in Pre-dynastic times-derived from equatorial Africa or was connected with faraway lands in later times, the association with Punt and other mythic regions enhanced his exotic nature. Just as his grotesque dysmorphism placed him in a liminal sphere, the alienation enhanced Bes" "otherness" - not unlike the physique of Queen Ati deviating from the ideal embodied by Hatshepsut. More than his actual origin, it is of utmost importance for understanding the religious significance that, despite his domestic and familial character, Bes was believed to hail from afar and thus remained a stranger. Together with lions and baboons, as well as other dwarfish figures, together with Shu and Thoth, as well as Hathor-Tefnis, Bes was welcomed in Egypt as he came from Nubia or Punt, or some other exotic land.

\footnotetext{
56 EMC inv. no. JE 14.276. For (dwarfs and) the Land of Punt, see: Dasen (1993, pp. 26-29); Aufrère (1998); Manzo (2017).

57 Bianchi (1997).

58 OGIS 130.
} 


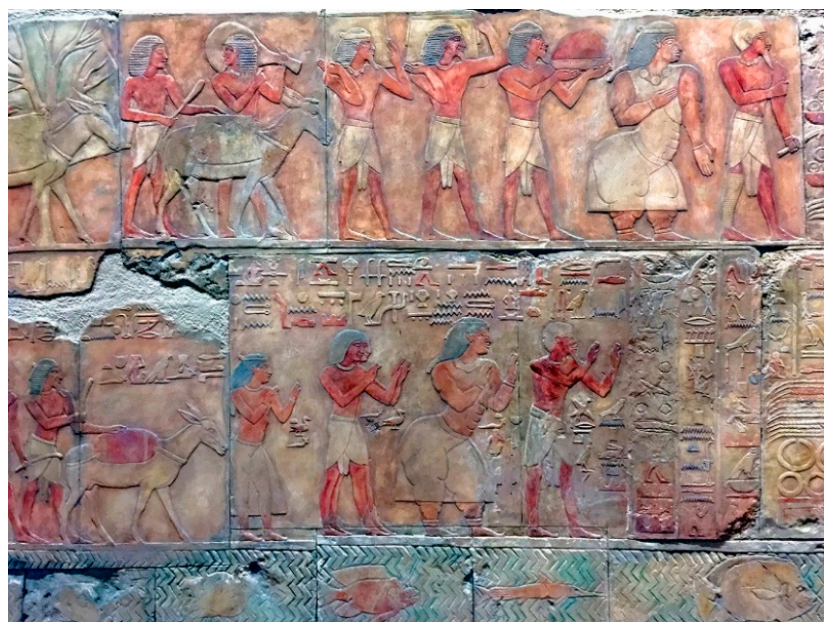

Figure 18. Queen Ati and King Perahu (from the Expedition to Punt); relief scene (detail); Deir el-Bahari, Upper Egypt; ca. 1475-1450 все; modern plaster cast, 1905 (ROM, no inv. no.). [Photo by the author; image courtesy of the Royal Ontario Museum, Toronto].

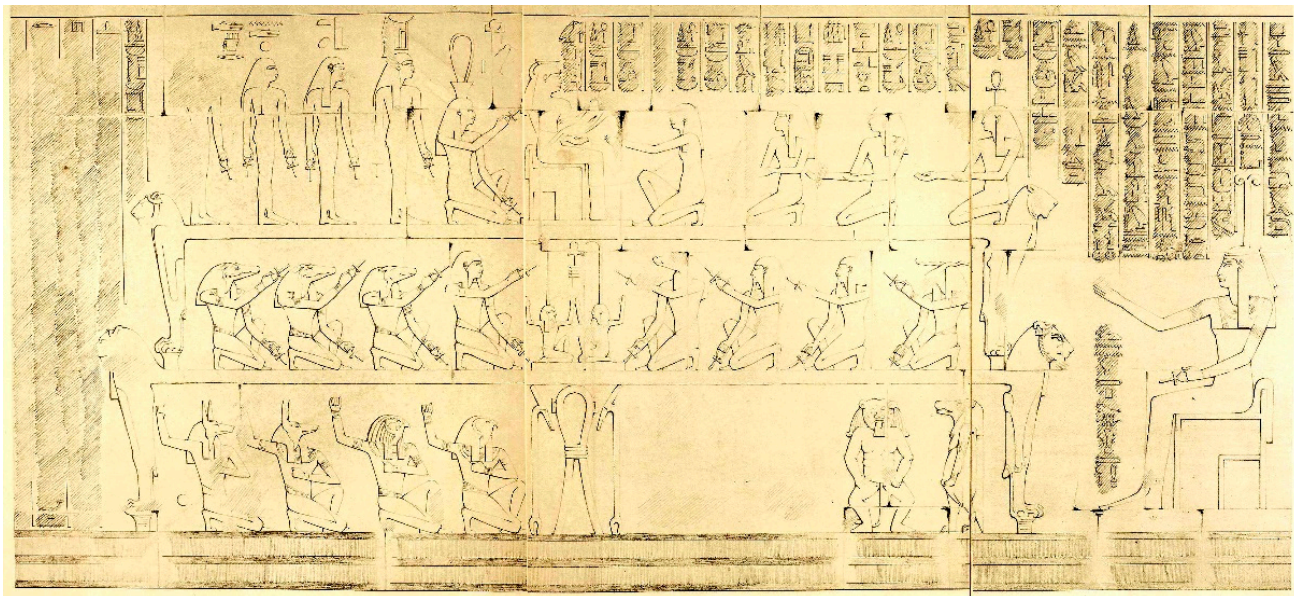

Figure 19. Hatshepsut's birth scene-from Édouard Naville, The Temple of Deir el Bahari (London, 1896), vol. 2, pl. 50. [Image courtesy of the University Library Heidelberg].

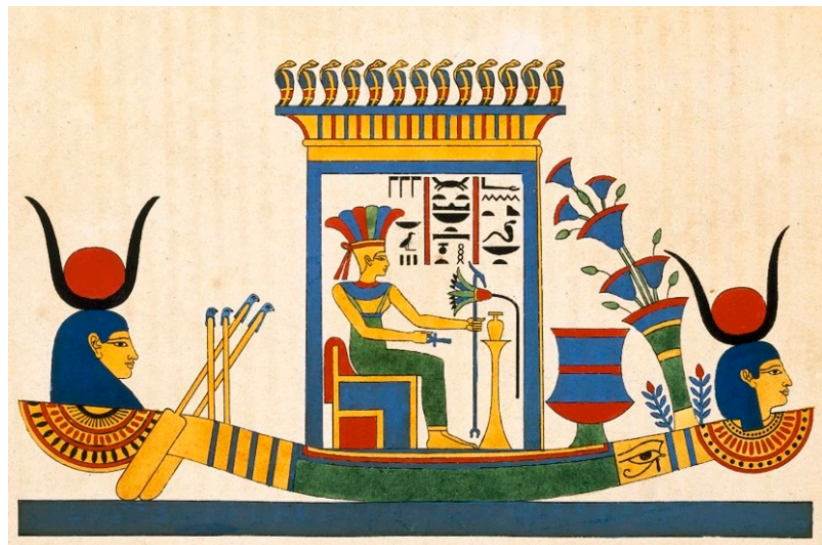

Figure 20. Anuqis in sacred barque-from Jean-François Champollion, Panthéon égyptien (Paris, 1823), pl. 20A. [Image courtesy of the Brooklyn Museum, New York].

When we, too, return from this detour to the topic at hand, we can turn to another bovine association connected with Bes. Namely, occasionally, Bes' conventional feathered crown included 
a representation of a bull among lotus or papyrus flowers, or within a shrine (naos) with Egyptian decorative elements. ${ }^{59}$ The bovine on Bes' crown is interpreted as the sacred bull of Memphis, the earthly manifestation of Ptah. ${ }^{60}$ We thus come full circle, from dwarfs to the son god Atum-Ra, via feline to bovine deities back to Ptah. The significance of rebirth will doubtless have played a part in this close assimilation of Bes and Apis.

\section{Master of the Universe}

While he did have a female companion in Besa, Bes more regularly appeared in the New Kingdom together with Thouëris (T3-wr.t, Taweret, "The Great One"; Figure 21)—particularly on ivory magic wands (or "knives") and furniture, but also (as we saw) in the scene of the divine birth of Hatshepsut. They are also very often found together in the same (funerary) context as amulets. ${ }^{61}$ Like Bes, the great hippopotamus goddess, with feline and crocodile features, was especially venerated as protectress of childbirth and fertility. Her most common attribute was the $s a$-sign $\left(R s_{3}\right)$ signifying "protection," on which she normally leaned. Thouëris' gentle nature contrasts well with the theriomorphic demon Ammit ('mm.t, the "Devourer of Souls"; Figure 22). She, too, was a composite being-in her case, consisting of the head of a crocodile, the upper body of a lion and the lower body of a hippopotamus. Fierce Ammit, like Apophis, symbolized the destructive force of chaos (Isfet)—the opposite of order and justice $\left(M a^{\prime} a t\right){ }^{62}$

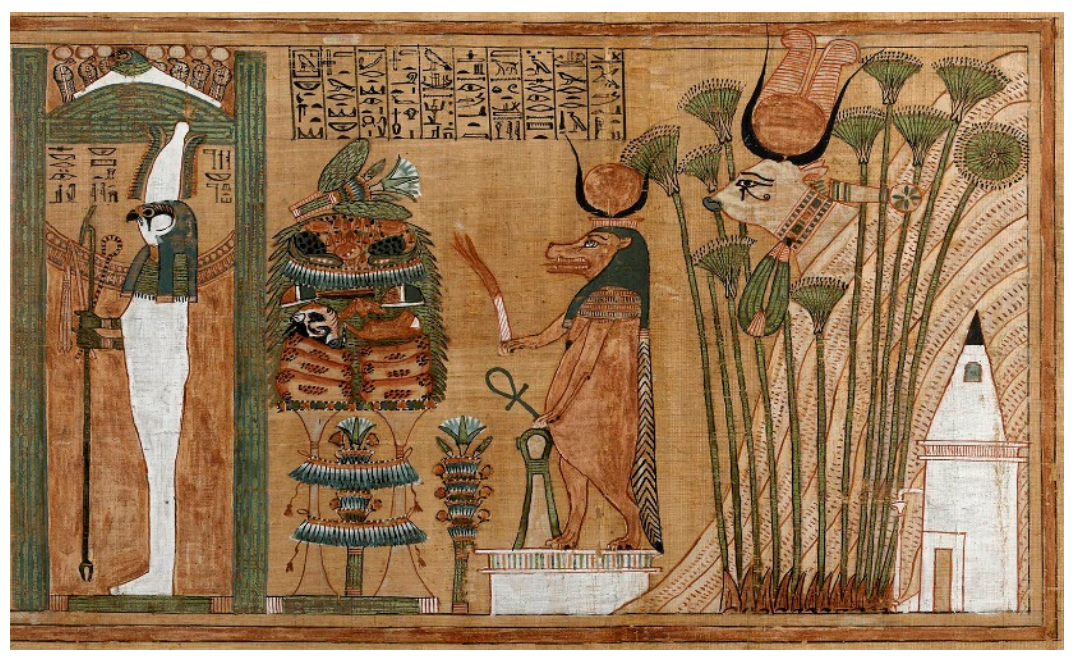

Figure 21. Thouëris and Hathor from the Papyrus of Ani (BM inv. no. EA 10.470,3); painted papyrus (detail); Thebes, Upper Egypt; ca. 1250 все. [Image courtesy of the Trustees of the British Museum, London].

59 APM inv. no. 7274 (terracotta figure, $40.7 \mathrm{~cm}$, Egypt, early Hellenistic); BM inv. no. EA 61.296 (terracotta figure, $49.5 \mathrm{~cm}$, Egypt, early Hellenistic); Ballod (1913, p. 85, n. 1, fig. 96); Dasen (1993, pl. 11, fig. 2).

60 Crawford (1980, pp. 1-42).

61 Andrews (1994, pp. 38-41, figs. 34, 37 and 39-40); Hart (2005, p. 49).

62 Altenmüller (1965, pp. 43-46). 


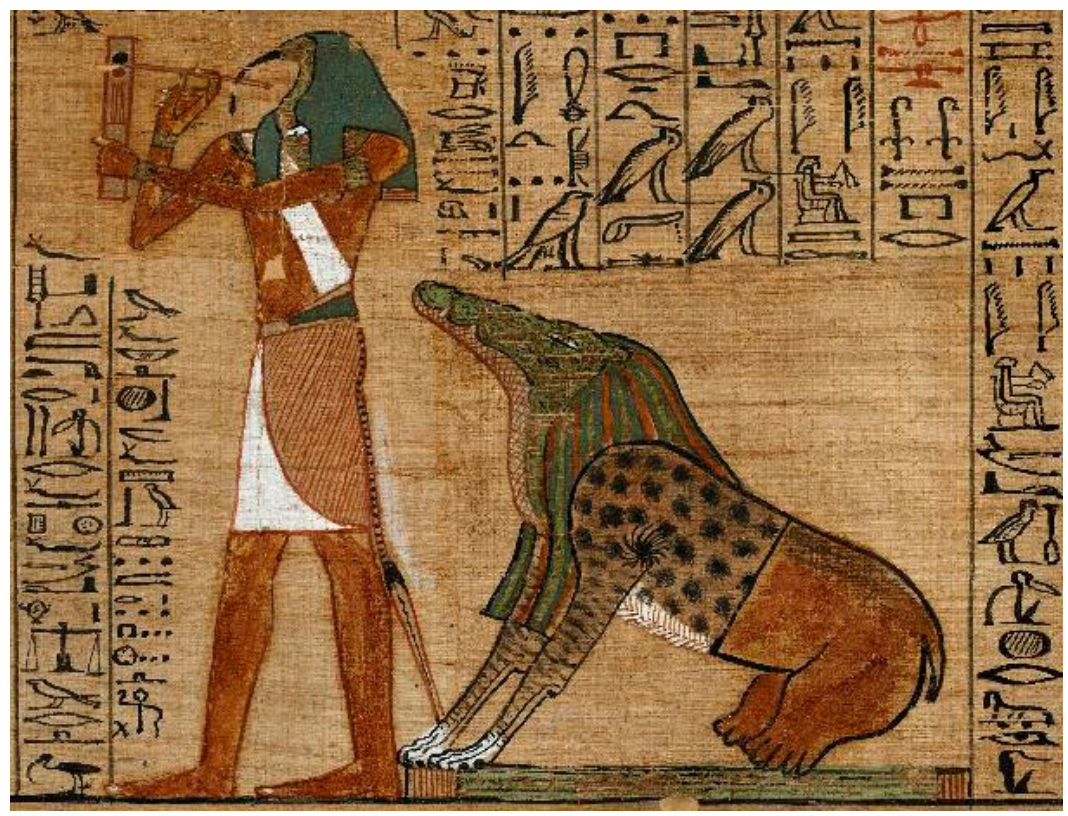

Figure 22. Thoth and Ammit from the Papyrus of Ani (BM inv. no. EA 10.470,3); painted papyrus (detail);

Thebes, Upper Egypt; са. 1250 все. [Image courtesy of the Trustees of the British Museum, London].

The presence of Bes in the birth chapels (mammisis) — not to mention the birth colonnade of Hatshepsut (at Deir el-Bahri)—reveals his essential role in the protection of the divine child. ${ }^{63}$ In Egypt, the archetypal divine infant, paradigm of the crown-prince, was Harpocrates ( $\mathbb{N}^{2}=\mathrm{g}^{\circ} H r . w-p_{3}-\underline{h} r d$, Herupakhered, "Horus the Child"), the son of Isis and Osiris, whose trials and tribulations after his father's death at the hands of Seth belong to the best-known Egyptian myths. ${ }^{64}$ Occasionally, figurines show Bes suckling the divine infant on his pendulous breasts, not unlike Isis Lactans nursing her child. ${ }^{65}$ The solar associations discussed earlier in relation to the sun god Ra are further confirmed by Bes' attendance of the sky god Horus ( Hr.w < *Hāru, the "Falcon"(?)), in particular the early morning sunrise.

The guardianship of Bes over Harpocrates is well expressed on the magic tablets (cippi)—of which the Metternich stela (now in New York) is the most well-known example-which feature the young Horus as Master of Animals, straddling crocodiles and clutching scorpions, serpents, lions, oryxes or other dangerous animals (Figure 23). ${ }^{66}$ As a rule, the head of Bes decorates the top of the stone. The primary function of these tables was apotropaic, the aversion of evil: that is, to ward off harm and danger. These Horus-cippi were, namely, considered to have curative powers for the purification of water that was poured in libation over the stone tablets. For the water thus consecrated was believed to heal from disease and poisons.

63 Brunner (1964, esp. pp. 179-80 and 186-87, pl. 9).

64 Brunner (1964).

65 Bulté (2001).

66 For Horus-cippi, now see: Sternberg-El Hotabi (1999); for the Metternich stela, see: Sander-Hansen (1956); Sternberg-El Hotabi (1999), I, 106, 110, fig. 55, and II, 72, pl. 17; Hart (2005), 49; Patch (2011), no. 155. 


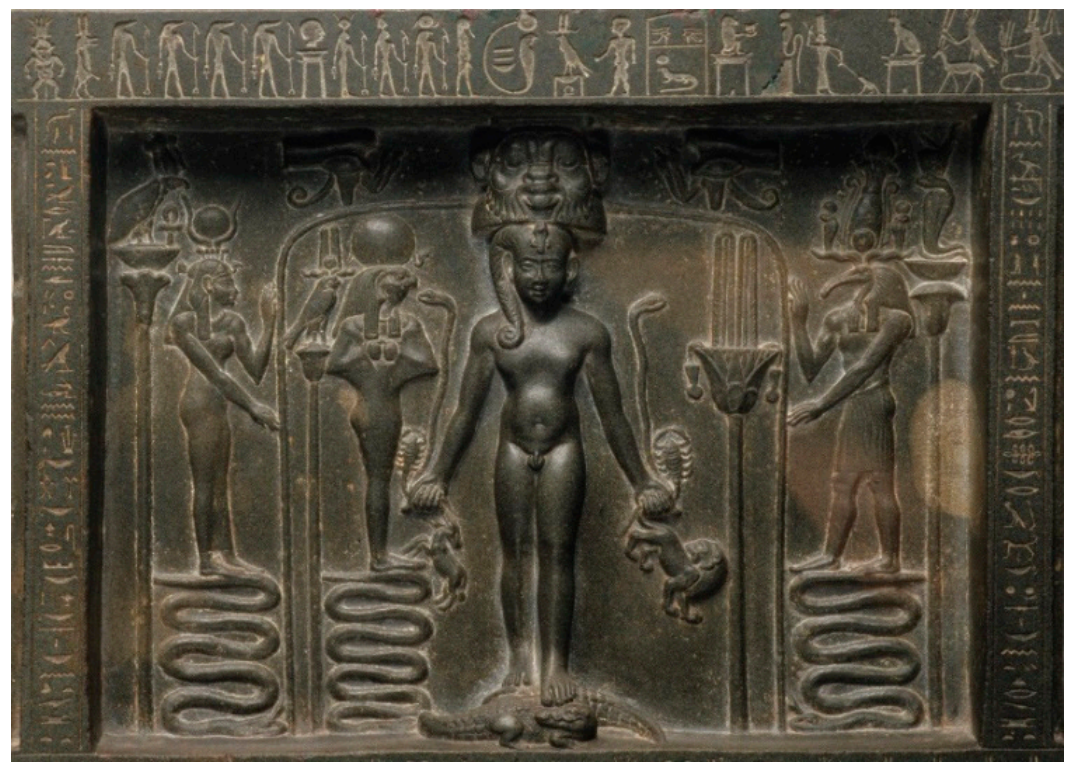

Figure 23. Horus Cippus (Metternich stela) (MMA acc. no. 50.85); greywacke stela; found in Alexandria, prob. from Heliopolis, Lower Egypt; ca. 360-343 все. [Image courtesy of the Metropolitan Museum of Art, New York].

At times, the head of Bes replaced that of Horus on such magic tablets. On the reverse side of the Metternich stela, indeed, a compound figure occurs with the head of Bes, who has both a human and a falcon body, and four arms as well as four feathered wings. He is crowned by a naos-type headdress, from which emerge the foreparts of seven animals (including a bull, a crocodile and a lion); the structure is surmounted by horizontal, undulating ram's horns; on top of that sits Heh (w $H$, "Infinity") flanked by four knives on either side. The Bes-headed figure holds anch ( $\left.{ }^{+}\right)$and djed ( $($) signs, knives and serpents, as well as scepters and spears in his hands. There are uraei coiling from his knees and knife blades pointing from his feet.

Very similar, though usually ithyphallic, figures are known also from Late Period and Ptolemaic bronze statuettes. In his terrifying appearance, this pantocrator is reminiscent of Pazuzu, the evil Mesopotamian demon whose name may even be related somehow to that of Bes (from *Bissw via *Bazu

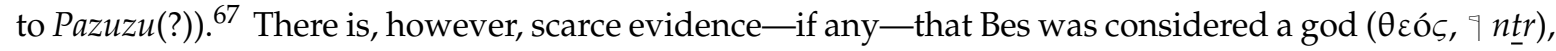
let alone worshipped as such, before the Graeco-Roman era. When a term other than his name Bes was used, it was "dwarf (nmw)." It would be surprising—-to say the least—if the leonine dwarf could ascend from his relatively humble position of guardian and attendant to the status of Master of the Universe. While frequently labelled "Bes Pantheos" in modern literature, the winged, Bes-headed figure should best be understood as an emanation of a syncretistic hypostasis of the creator god Amun (Figure 24). ${ }^{68}$

Since the Hellenistic period, and particularly during the Roman Imperial age, the warrior Bes-wielding his short sword - could be accompanied by another composite theriomorphic demon: the similarly leonine Tithoës (Tı $\bullet$ oñ $\varsigma$, Twtw, Tutu, the "Statuesque"(?); Figure 25). ${ }^{69}$ He was considered the "mighty (' $\left.3 p h t^{i} i\right)$ " son of Neith-Athena. This adorable monster was regularly conceived as a sphinx, with the head of a man, the body of a lion and a tail in the shape of an upright cobra. Tithoës could be bi- or even trifrons, with the head of a crocodile, lion, ram, falcon and/or ibis; he might wear a double-plumed crown atop horizontal ram's horns surmounted by a sun disc flanked by uraei; he

67 Pazuzu, of course, is the demon who possesses the twelve-year old Regan (actress Linda Blair) in the classic horror film The Exorcist directed by William Friedkin (1973), based on the homonymous book by William Peter Blatty (1971).

68 Dasen (1993, pp. 65-66); Bąkowska (2001); Bianchi (2011, pp. 192-94, no. 74).

69 LÄ s.v. 'Tithoes'; Kaper (2003). 
could be decked with the royal nemes or have a lion's mane for hair. The sphinx could also have large feathered wings on his back; knives might point from his paws, or snakes, scorpions or griffons might sprout from them. Tithoës appears on monuments from the Saite Period (26th Dyn., 664-525 вСЕ), Ptolemaic and Imperial temple relief scenes, Graeco-Roman votive stelae, statuettes and amulets, and Roman coins as well as a wall painting at Caranis. His fearful apotropaic quality is particularly related to the victory over evil. The partially leonine beings, Tithoës and Bes, thus share the mastery over malevolent demons.

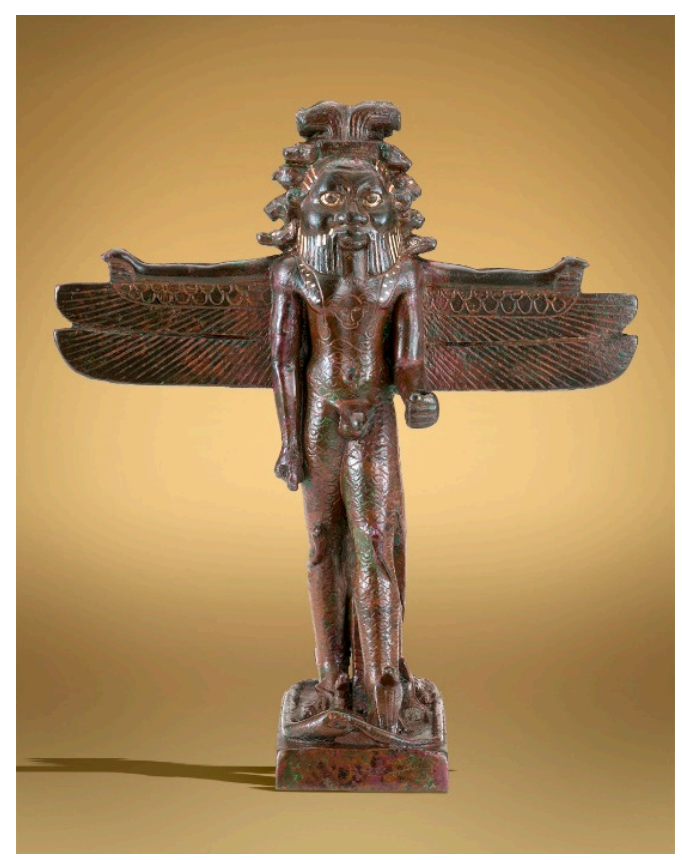

Figure 24. Pantheistic "Bes" (FGA inv. no. ARCH-EG 170); bronze figurine; found in Syria, from Egypt; са. 6th-1st cent. вСе. [Photo by André Longchamp; image courtesy of Fondation Gandur pour l'Art, Geneva].

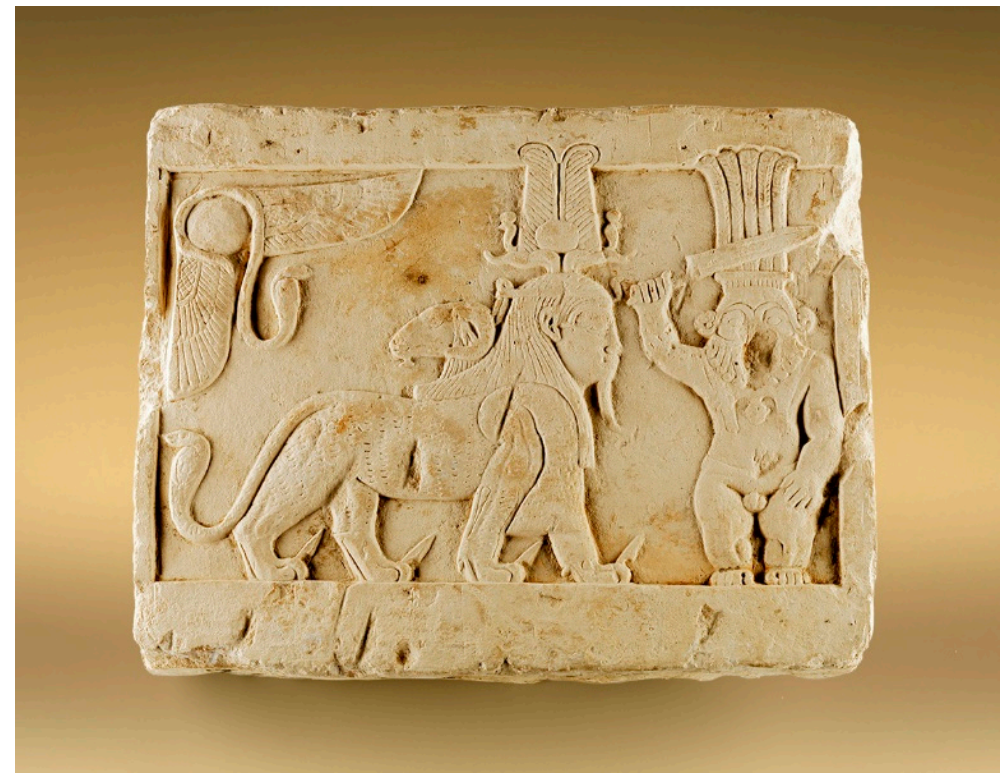

Figure 25. Bes and Tithoës (APM inv. no. 7757); limestone relief; Egypt; ca. 1st-3rd cent. ce. [Photo by Stephan van der Linden; image courtesy of the Allard Pierson Museum, Amsterdam]. 


\section{Bipolar Dualism of Bes}

Egyptian religion reveals a theological conception of essential and existential opposites, which can be expressed in a dualistic structure of associations (see: Appendix A: The Dualities of Bes). The foregoing examination of the Bes figure, unsurprisingly then, does indeed lay bare his well-nigh bipolar character. When we now turn to these dualistic aspects of Bes we will be better able to illuminate his religious significance. In appearance the leonine dwarf is lovely ugly. That is to say, Bes is not attractive or gracious, but still charming despite his hideous dysmorphism-which was certainly a deviation far from the Egyptian ideals of perfection and beauty. His grotesquely grimacing face is at once hilarious as it is frightening. In short, the physical manifestation of the Bes figure is simultaneously benevolent and malevolent.

The familiar image of Bes is a composite of anthropomorphic and theriomorphic elements-part dwarfish, part feline. He emerged from the magical realm of the world of demons, and gradually seems to have obtained a more numinous status, until in the Roman Imperial age he sporadically at least acquired divine worship. His nature was that of a fighter, a soldier and a warrior, as well as a dancer and musician. In all, Bes was a guardian demon—attending many of the major gods of Egypt and offering protection to the general populace of the land, too.

The animalistic associations that have been reviewed illustrate that Bes' character was both benign and malignant. Like Hathor-Tefnis, his animal nature would cause him to be now kind and gentle, now angry and fierce. He could thus be friend or foe depending on the circumstances he faced. With his beastly appearance he was weird-in the sense of strange, odd. Yet, he was indelibly familiar-as protector of the household even homely: in a way, tame and domesticated. By no means, however, was he cultured or civilized. His wild character still rendered him uncontrollable and unpredictable.

Such paradoxical fusion of seemingly contradictory aspects can even be found in Bes' supposed origin. For, the leonine dwarf hails both from Egypt and from Punt. He is native yet foreign, always close though distant. The Bes image is familiar as well as exotic, common but strange, and, due to this alienation, he represents neither the norm nor the ideal.

In terms of his functions, Bes provided protection from danger-a gesture of a loving embrace. Yet, he simultaneously averted harm - an act of violent aggression. It is insufficient to state-as do most scholars-that Bes' function was essentially apotropaic, although warding off evil was certainly one of his important roles. Through his terrifying attitude he frightened and fought off enemies. His role as dancer and musician, however, was placating in nature: to appease the gods-especially the wrath of Hathor-Tefnis. While his participation in religious festivals was meant to bring good cheer-a ritual act of jubilation - this role also extended into the private sphere to bring personal joy and happiness. His regenerative importance, additionally, contributed to the fulfilment and happiness of family life in all facets of reproduction - from virility and sexuality, via fertility and fecundity, to childbirth and growth. The protection of life in general and of the household in particular furthermore encompassed the curative powers of Bes, both in terms of medicinal healing and magical purification.

The dualistic aspects of Bes, moreover, bring his religious significance into sharper focus. Through his protection of the sun god, together with lions and dwarfs, baboons and scarabs, Bes was guardian of the sun god Ra-thus expressing his solar concern, particularly related to the sunrise at dawn in the east. The leonine dwarf operates at day in the light, between heaven and earth. His duties center on life and birth, creation and order. Bes then represents all that is good. As a concomitant of this network of associations, it is important to note that Bes has little or no lunar significance, and little or no role either involving the moon god or the night, neither sunset nor the west, neither dusk nor darkness. His image occurred on headrests and torches, though that stems more from Bes' role as guardian than from a specifically nocturnal function. He was not particularly connected with water bodies (rivers, seas, the ocean) or deities embodying water. Bes can hardly be found in scenes from the Underworld—unlike lions and baboon. Similarly, he played little part in death—as he was rather 
concerned with rebirth and regeneration. ${ }^{70}$ Thus, he was neither a destructive force nor an agent of chaos. As a guardian demon of life, Bes was not an emanation of evil.

\section{Guardian Demon of Life}

By means of conclusion, let us review the findings of the present study. Scholars have often focused on the dwarfish aspect of the Bes image-thus ignoring or downplaying the leonine features of his appearance. For the Bes figure can be found among the company of guardians of the solar circuit-where one can also find lions, dwarfs and baboons. He was especially concerned with the sunrise, hailing the sun god Ra emerging from the netherworld. In Egyptian religion, this event was emblematic of ever-rejuvenating royal power. Just as the sun emerged each morning at dawn from the distant horizon in the east, so lions and dwarf, baboons and Bes himself were from faraway, exotic or even mythical lands-whether Nubia or farther from Egypt still. Similarly, the Myth of the Solar Eye told of the time when the daughter of Ra had abandoned her father and had left Egypt for distant lands - either Nubia or Punt. Significantly, this leonine daughter of Ra, Tefnis, was said to be fierce like the lioness Sachmis and gentle like the feline Bastis. And while Sachmis was connected with healing, Bastis was connected with childbirth. The warrior aspect of the Aha-Bes image expressed identical themes.

From his leonine features, we arrive at Bes' link with bovine associations. For, in the company of Hathor, Bes appears as a dancer and musician. He performs rituals of jubilation, to appease the wrathful goddess. To be sure, Hathor was identified with Tefnis as she returned from Nubia or Punt-attended by baboons and dwarfs, singing and dancing and playing music. We have seen that Bes was present-with Thouëris-at the divine birth of Hatshepsut. Likewise, Bes came to perform an essential role for the birth of the divine prince-incidentally, called the Kamutef ( $K_{3}-m w t-f$, "the Bull of his Mother"). Egyptian bull cults not only presented living bulls as earthly manifestations of the chief local god, sacred bulls such as Apis moreover were considered archetypical emanations of the crown-prince. Here, in other words, we find Bes connected with the center of power.

Modern scholarship emphasizes the apotropaic and regenerative functions of Bes. While these were definitely important roles the leonine dwarf performed, this paper has aimed to illustrate that his religious significance encompassed a wider sphere of influence. The Bes image certainly is grotesque, malformed and bestial in its features. In this bimorphic or composite appearance, Bes shared the liminal space inhabited by demons and monsters in Egypt—-between gods and humans. Indeed, the figure of Aha-Bes first occurs among such monstrous demons on magic wands and amulets. Their frightful, terrifying, demonic demeanor is surely apotropaic. The identification of Bes with Aha presents the leonine fighter as an averter of evil forces $(\dot{\alpha} \lambda \varepsilon \xi \xi \kappa \alpha \kappa o \varsigma)$.

Hence the warrior configuration with weapons such as a knife or a sword, a shield and other elements of a military outfit. In this role, Bes specifically wards off death and disease, harm and danger. This role additionally engendered the assimilations with Horus (or, rather, Harpocrates) and Pataecus (the dwarfish Ptah). The figure of the Master of Animals, especially the strangler

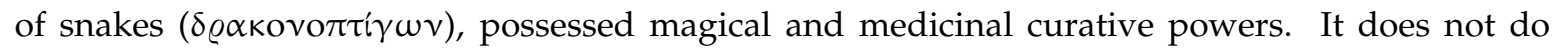
Bes justice, however, to explain his performance as dancer and musician in terms of apotropaism. For his identifications with Hity and Ihy reveal a placating duty, providing merriment to appease the gods-especially the wrathful Hathor-Tefnis—and bring joy to the populace. Bes' comic hideousness must also have given Egyptians pleasure, making them laugh and smile.

There is, in other words, benevolence in his malevolence. The animalistic and demonic aspects associated with Bes reveal him to be a guardian demon-in a manner like the Agathodaemon ('A $\gamma \alpha \theta$ ó $\Delta \alpha i \mu \omega v)$. Bes was the protector of the birth and growth of children, the guardian of the domestic sphere and family life within the household. This protection extended into all aspects of fertility and

70 For a noteworthy exception, see: Ballod (1913, p. 101, fig. 116); Parlasca (2010, pp. 229-30, n. 44). 
procreation, sexuality and virility. It also encompassed furniture and cosmetics, jewelry and amulets. Once more, Bes was a figure of cheerful festivities-a dancer and musician (a performance he shared with baboons). It is important to emphasize that his contribution to and participation in merriment, joy, jubilation and insobriety involved not only the public sphere of official religious ceremonies, but also the private sphere of individual households and personal happiness. Bes, in short, was a beer-drinker and hell-raiser. The animalistic aspects associated with him in ancient Egyptian popular religion show lovely ugly Bes to be a guardian demon of life on earth.

Funding: This research received no external funding.

Acknowledgments: This paper emerged from several inspiring conversations with Robert A. Lunsingh Scheurleer (former chief curator and director, Allard Pierson Museum, Amsterdam), Olaf E. Kaper (Egyptologist, Leiden University), Christian E. Loeben (Egyptologist and curator, August Kestner Museum, Hanover), and most of all Robert S. Bianchi (former chief curator and curator of archaeology, Fondation Gandur pour l'Art, Geneva), i.a., in preparation for an exhibition on the subject and the conference on "Animals in Ancient Material Culture," which was organized at the Allard Pierson Museum (15-16 October 2015), Amsterdam. I would also like to convey thanks to the anonymous reviewers for their corrections and suggestions, and to Rose Campbell for proofreading the text. While I am very grateful for all their insights, the ideas expressed in this paper do not necessarily represent those of the people named above-and I am solely responsible for the faults contained in the arguments presented here.

Conflicts of Interest: The author declares no conflict of interest.

\section{Abbreviations}

ÄMGS Egyptian Museum [ت̈gyptisches Museum] “Georg Steindorff”, Leipzig.

APM Allard Pierson Museum, Amsterdam.

BD Faulkner, Raymond O. (trans.). 1972. The Ancient Egyptian Book of the Dead.

BD Edited by Carol A.R. Andrews. Austin: University of Texas Press.

BM British Museum, London.

EMC Egyptian Museum, Cairo.

EMT Egytpain Museum, Turin

FGA Fondation Gandur pour l'Art, Geneva.

$L \ddot{A} \quad$ Helck, Wolfgang and Eberhard Otto (eds.). 1972-1992. Lexikon der Ägyptologie.

$\begin{array}{ll} & \text { Wiesbaden: Harrassowitz. } \\ \text { LACMA } & \text { Los Angeles County Museum, L.A., Calif. }\end{array}$

LD Lepsius, Carl Richard. 1897-1913. Denkmäler aus Aegypten und Aethiopien. Leipzig.

MMA Metropolitan Museum of Art, New York.

OGIS Dittenberger, Wilhelm (ed.). 1903-1905. Orientis Graeci Inscriptiones Selectae. Supplementum Sylloges Inscriptionum Graecarum, 2 vols. Leipzig.

RÄRG Bonnet, Hans (ed.). 1952. Reallexikon der ägyptischen Religionsgeschichte. Berlin: De Gruyter.

RE Pauly, August, Georg Wissowa, and Wilhelm Kroll (eds.). 1893-1980. Realencyclopädie der classischen Altertumswissenschaft. Stuttgart: Metzler.

RML Roscher, Wilhelm H. (ed.). 1884-1937. Ausführliches Lexikon der Griechischen und

RMO Römischen Mythologie. Leipzig.

ROM Royal Ontario Museum, Toronto.

WAM Walters Art Museum, Baltimore, Md.

\section{Appendix A. The Dualities of Bes}

\begin{tabular}{ll}
\hline Appearance & \\
Lovely & Ugly \\
Charming & Hideous \\
Hilarious & Frightful \\
Benevolent & Malevolent \\
\hline
\end{tabular}




\begin{tabular}{|c|c|}
\hline \multicolumn{2}{|l|}{ Nature } \\
\hline Numinous & Demonic \\
\hline Dwarf & Animal \\
\hline Dancer & Fighter \\
\hline Musician & Soldier \\
\hline Guardian & Warrior \\
\hline \multicolumn{2}{|l|}{ Character } \\
\hline Benign & Malignant \\
\hline Gentle & Fierce \\
\hline Kind & Angry \\
\hline Friend & Foe \\
\hline Familiar & Weird \\
\hline Homely & Beastly \\
\hline Tame (domesticated) & Wild (uncontrollable) \\
\hline \multicolumn{2}{|l|}{ NB: not cultured or civilized } \\
\hline \multicolumn{2}{|l|}{ Origin } \\
\hline Egypt & Punt \\
\hline Native & Foreign \\
\hline Close & Distant \\
\hline Familiar & Exotic \\
\hline Common & Other (alien) \\
\hline \multicolumn{2}{|l|}{ NB: not normal or ideal } \\
\hline \multicolumn{2}{|l|}{ Functions } \\
\hline Protection (from danger) & Aversion (against harm) \\
\hline Placation (appeasement) & Apotropaism (warding off evil) \\
\hline Happiness (personal joy) & Jubilation (ritual cheers) \\
\hline Reproduction (regeneration) & Healing (magical purification) \\
\hline \multicolumn{2}{|l|}{ Significance } \\
\hline Solar (Sun) & NB: not Lunar (Moon) \\
\hline esp.: sunrise, dawn, east & not sunset, dusk, west \\
\hline Day & NB: not Night (though sleep) \\
\hline Light & NB: not Dark \\
\hline Sky & NB: not Ocean \\
\hline Earth & NB: not Underworld \\
\hline Life & NB: not Death \\
\hline Birth & but Rebirth \\
\hline Creation & NB: not Destruction \\
\hline Order & NB: not Chaos \\
\hline Good & NB: not Evil \\
\hline
\end{tabular}

\section{References}

Altenmüller, Hartwig. 1965. Die Apotropaia und die Götter Mittelägyptens: Eine typologische und religionsgeschichtliche Untersuchung der sogenannten "Zaubermesser" des Mittleren Reichs. 2 vols. Ph.D. dissertation, Ludwig-Maximilian University, Munich, Germany.

Andrews, Carol. A. R. 1994. Amulets of Ancient Egypt. London: British Museum Press.

Aufrère, Sydney. 1998. Un prolongement méditerranéen du mythe de la Lointaine à l'époque tardive. In Le Commerce en Égypte Ancienne. Edited by Nicolas Grimal and Bernadette Menu. Cairo: Institut français d'archéologie orientale, pp. 19-39.

Bąkowska, Grażyna. 2001. Bes Pantheos: Some Remarks Concerning his Representation on Magical Gems. In Proceedings of the First Central European Conference of Young Egyptologists. Edited by Joanna Popielska-Grzybowska. Warsaw: Institute of Archaeology Warsaw University, pp. 11-14. 
Ballet, Pascale. 2012. Bès et Béset. In L'Orient Romain et Byzantin au Louvre. Edited by Nicolas Bel, Cécile Giroire, Cécile Giroire, Marie-Hélène Rutschowscaya and Pierre-Louis Gatier. Paris: Musée du Louvre, pp. 290-93.

Ballod, Franz. 1913. Prolegomena zur Geschichte der Zwerghaften Götter in Ägypten. Ph.D. dissertation, Ludwig-Maximilian University, Munich, Germany.

Bianchi, Robert Steven. 1997. The Theban Landscape of Rameses II. In Ancient Egypt, the Aegean, and the Near East: Studies in Honor of Martha Rhoads Bell. Edited by Jacqueline S. Phillips. San Antonio: Van Siclen, vol. 1, pp. 87-94.

Bianchi, Robert Steven. 2011. Ancient Egypt-Art and Magic: Treasures from the Fondation Gandur pour l'Art. St. Petersburg, Fla.: Museum of Fine Arts.

Bissing, Friedrich W. von. 1925. Eine hellenistische Bronzefigur des Gottes Bes. Mitteilungen des Deutschen Archäologischen Instituts, Athenische Abteilung 50: 123-32, pls. 4-5.

Borghouts, Joris F. 1971. Magical Texts of Papyrus Leiden I 348. Leiden: Brill.

Brunner, Hellmut. 1964. Die Geburt des Göttkonigs: Studien zur überlieferung eines altägyptischen Mythos. Wiesbaden: Harrassowitz.

Budde, Dagmar. 2008. 'Kommt und seht das Kind': Kindgötter im Festgeschehen der griechisch-römischen Geburtshäuser Ägyptens. In Fest und Eid: Instrumente der Herrschaftssicherung im Alten Orient. Edited by Doris Prechel. Würzburg: Ergon, pp. 13-48.

Bulté, Jeanne. 2001. Iconographie originale d'un Bès 'nourricier' inédit: Illustration d'une malédiction obscène. Revue d'Égypte 52: 57-67.

Chabouillet, Anatole. 1861. Description des Antiquités et Objets D'art Composant le Cabinet de M. Louis Fould. Paris: Claye.

Clarysse, Willy, Beatrijs Van Maele, and Jan Quaegebeur. 1985. Athena, Neith and Thoeris in Greek Documents. Zeitschrift für Papyrologie und Epigrafik 60: 217-32.

Cooney, John D. 1954. The Lions of Leontopolis. Brooklyn Museum Bulletin 15: 17-30.

Crawford [Thompson], Dorothy J. 1980. Ptolemy, Ptah and Apis in Hellenistic Memphis. In Studies on Ptolemaic Memphis. Edited by Dorothy J. Crawford, Jan Quaegebeur and Willy Clarysse. Louvain: Peeters, pp. 1-42.

Dasen, Véronique. 1988. Dwarfism in Egypt and Classical Antiquity: Iconography and Medical History. Medical History 32: 252-76. [CrossRef]

Dasen, Véronique. 1990. L'image du nain dans l'Antiquité: Aspects médicaux et socio-religieux de la représentation du corps. Bulletin der Naturforschenden Gesellschaft Freiburg 79: 16-43.

Dasen, Véronique. 1993. Dwarfs in Ancient Egypt and Greece. Oxford: Oxford University Press.

Daumas, François. 1968. Les propylées du temple d'Hathor à Philæ. Zeitschrift für Ägyptische Sprache und Altertumskunde 95: 1-17, pls. 1-6.

Delpech-Laborie, Jean. 1941. Le dieu Bès, nain, pygmée ou danseur? Chronique d'Égypte 16: 252-54.

El-Sayed, Ramadan. 1976. Deux aspects nouveaux du culte à Saïs: -un prophète du nain de Neith, -des châteaux d'Ageb. Bulletin d'Institut Françoise d'Archéologie Orientale 76: 91-100.

Erman, Adolf. 1882. Neue arabische Nachahmungen griechischer Münzen. Zeitschrift für Numismatik 9: 296-301, pl. 6.

Fink, Martin. 2011. Bes, Thoeris und Harpokrates: Alltagsreligion im Schatten der Tempel. In KultOrte: Mythen, Wissenschaft und Alltag in den Tempeln Ägyptens. Edited by Daniel von Recklinghausen and Martin A. Stadler. Berlin: Manetho, Wiesbaden: Harrassowitz, pp. 160-81.

Graves, Carl. 2012. Intercultural Communication: Egypt and Nubia c. 2543-1076 вс. In Connections: Communication in Ancient Egypt. Edited by Carl Graves and Steven R. W. Gregory. Birmingham: University of Birmingham, no pp. Available online: https://www.birmingham.ac.uk/research/activity/connections/Essays/CGraves.aspx (accessed on 9 April 2019).

Grenfell, Alice. 1902. The Iconography of Bes, and of Phoenician Bes-Hand Scarabs. Proceedings of the Society of Biblical Archaeology 24: 21-40.

Hart, George L. 2005. The Routledge Dictionary of Egyptian Gods and Goddesses. London and New York: Routledge. Hawass, Zahi. 2000. The Temple of Bes. In Valley of the Golden Mummies. New York: American University in Cairo Press, pp. 168-73.

Hornung, Erik, and Elisabeth Staehelin. 1974. Studien zum Sedfest. Geneva: Ägyptologisches Seminar, Universität Basel, Edition de Belles-Lettres. 
Hückel, R. 1934. Über Wesen und Eigenart der Pataiken. Zeitschrift für Ägyptische Sprache und Altertumskunde 70 : 103-7. [CrossRef]

Jackson, Lesley. 2018. Sekhmet and Bastet: The Feline Powers of Egypt. London: Avalonia.

Junker, Hermann. 1911. Der Auszug der Hathor-Tefnut aus Nubien. Berlin: Reimer.

Kákosy, László. 2002. À propos des statues guérisseuses et d'une statues de Bès au musée du Louvre. In La Magie Egyptienne: A la Recherche d'une Définition. Edited by Yvan Koenig. Paris: Musée du Louvre, pp. 273-84.

Kaper, Olaf E. 2003. The Egyptian God Tutu: A Study of the Sphinx-God and Master of Demons with a Corpus of Monuments. Louvain: Peeters.

Konrad, Kirsten. 2007. Bes zwischen Himmel und Erde: Zur Deutung eines Kopfstützen-Amuletts. Zeitschrift für ägyptische Sprache und Altertumskunde 134: 134-37. [CrossRef]

Kozma, Chahira. 2006. Dwarfs in Ancient Egypt: Historical Review. American Journal of Medical Genetics 140A: 303-11. [CrossRef] [PubMed]

LeBlanc, Marc J. 2015. The Zoomorphic Transformation of the King in Early Egyptian Royal Military Victory Rituals and its Relationship to the Sed Festival. In Apprivoiser le sauvage/Taming the Wild. Edited by Magali Massiera, Bernard Mathieu and Frédéric Rouffet. Montpellier: Cahiers Égypte nilotique et méditerranéenne, pp. 229-43.

Malaise, Michel. 1987. Bès et Béset: Métamorphoses d'un démon et naissance d'une démone dans l'Égypte ancienne. In Anges et Démons: Actes du colloque de Liege et de Louvain-La-Neuve, 25-26 novembre 1987. Edited by Julien Ries and Henri Limet. Louvain: Centre d'Histoire des Religions, pp. 53-70.

Malaise, Michel. 1990. Bès et es croyances solaires. In Studies in Egyptology Presented to Miriam Lichtheim. Edited by Sarah Israelit-Groll. Jerusalem: Hebrew University, Magnes Press, pp. 670-729.

Malaise, Michel. 2010. La gens isiaque de retour au pays. In Isis on the Nile. Edited by Laurant. Bricault and Miguel John Versluys. Leiden: Brill, pp. 1-6.

Manniche, Lise. 2015. 'Bes' Rooms. In Lotus and Laurel: Studies on Egyptian Language and Religion in Honour of Paul John Frandsen. Edited by Rune Nyord and Kim Ryholt. Copenhagen: Museum Tusculanum Press, Chicago: University of Chicago Press, pp. 209-32.

Manzo, Andrea. 2017. BiAw Pwnt in the Archaeological Record: Preliminary Results and Perspective of Research. In Cultural and Linguistic Transition Explored: Proceedings of the ATrA Closing Workshop Trieste, May 25-26, 2016. Edited by Ilaria Micheli. Trieste: Università di Trieste, pp. 87-108.

Mariette, Auguste F. F. 1869. Abydos: Description des fouilles I: Ville antique-Temple de Séti. Paris: Franck.

Maspero, Gaston. 1883. Guide du visiteur au Musée Boulaq. Cairo: Musée de Boulaq.

Meeks, Dimitri. 1992. Le nom du dieu Bès et ses implications mythologiques. In The Intellectual Heritage of Egypt: Studies Presented to László Kákosy by Friends and Colleagues on the Occasion of his 60th Birthday. Edited by Ulrich. Luft. Budapest: Eötvös Loránd University, pp. 423-36.

Murnane, William. 1981. The Sed-Festival: A Problem in Historical Method. Mitteilungen des deutschen archäologischen Instituts, Abteilung Kairo 37: 369-76.

Nagy, Adrienn. 2007. Jambes arquées: The African Dwarf as the Source of Inspiration of Huwawa and Bes. In Proceedings of the Fourth Central European Conference of Young Egyptologists. Edited by Kata Endreffy and András Gulyás. Budapest: Eötvös Loránd University, pp. 299-310.

Onderka, Pavel, and Vlastimil Vrtal. 2018. The Typhonium of Wad Ben Naga. In Nubian Archaeology in the XXIst Century: Proceedings of the Thirteenth International Conference for Nubian Studies (Neuchâtel, Sept. 1-6, 2014). Edited by Matthieu Honegger. Louvain: Peeters, pp. 415-22.

Parlasca, Klaus. 2010. Anubis mit dem Schlüssel in der kaiserzeitlichen Grabkunst Ägyptens. In Isis on the Nile. Edited by Laurant Bricault and Miguel John Versluys. Leiden: Brill, pp. 221-32.

Patch, Diana C., ed. 2011. Dawn of Egyptian Art. New York: The Metropolitan Museum of Art.

Petrie, W. M. Flinders. 1889. Hawara, Biahmu, and Arsinoe. London: Trubner.

Petrie, W. M. Flinders. 1906. The Religion of Ancient Egypt. London: Constable.

Pierrat-Bonnefois, Geneviève. 2009. Les patèques. In Avant la Naissance: 5000 ans d'images. Edited by René Frydman, Émile Papiernik, Cédric Crémière and Jean-Louis Fischer. Paris: Conti, Le Havre: Muséum d'histoire naturelle, p. 25.

Pinch, Geraldine. 1993. Votive Offerings to Hathor. Oxford: Oxford University Press.

Pleyte, Willem. 1881. Chapitres Supplémentaires du Livre des Morts 162, 162*, 163: Traduction et Commentaire. Leiden: Brill. 
Preys, René. 2006. Le mythe de la Lointaine: Loinne dangereuse et déesse bénéfique. In Sphinx: Les Gardiens de l'Égypte. Edited by Eugène Warmenbol. Brussels: Mercator, pp. 141-51.

Quirke, Stephan G. J. 2016. Birth Tusks: The Armoury of Health in Context_Egypt 1800 вс. London: Golden House. Romano, James F. 1980. The Origin of the Bes-Image. Bulletin of the Egyptological Seminar 2: 39-56.

Romano, James F. 1989. The Bes-Image in Pharaonic Egypt. Ph.D. dissertation, New York University, New York, NY, USA.

Russmann, E. R. 2001. Eternal Egypt: Masterworks of Ancient Art from the British Museum. London: British Museum Press.

Sander-Hansen, Constantin E. 1956. Die Texte der Metternichstele. Copenhagen: Munksgaard.

Scheurleer, Robert A. Lunsingh. 1987. Bes, Demon in Egypte. Allard Pierson Mededelingenblad 39: 1-13.

Six, Jan. 1885. Specimen Literarium Inaugurale de Gorgone. Amsterdam: de Roever Kröber-Bakels.

Spiegelberg, Wilhelm. 1917. Der ägyptische Mythos vom Sonnenauge: nach dem Leidener demotischen Papyrus I 384. Strasbourg: Schultz.

Sternberg-El Hotabi, Heike. 1999. Untersuchungen zur Überlieferungsgeschichte der Horusstelen: Ein Beitrag zur Religionsgeschichte Ägyptens im 1. Jahrtausend v. Chr. Wiesbaden: Harrassowitz, 2 vols.

Stricker, Bruno H. 1956. Bes de danser. Oudheidkundige Mededelingen uit het Rijkmuseum van Oudheden te Leiden 37: 35-48.

Takács, Gábor. 2002. The Origin of the Name Bes (bs). In Le Lotus Qui Sort de Terre: Mélanges Offerts à Edith Varga. Edited by Hedvig Győry. Budapest: Musée des Beaux-Arts, pp. 455-58.

Töpfer, Susanne. 2014. The Physical Activity of Parturition in Ancient Egypt: Textual and Epigraphical Sources. Dynamis 34: 317-35. [CrossRef]

Volokhine, Youri. 1994. Dieux, masques et hommes: à propos de la formation de l'iconographie de Bès. Bulletin de la Société d'Égyptologie de Genève 18: 81-95.

Volokhine, Youri. 2010. Quelques aspects de Bes dans les temples égyptiens de l'époque Gréco-Romaine. In Isis on the Nile. Edited by Laurant Bricault and Miguel John Versluys. Leiden: Brill, pp. 233-55.

Wolff, Hans F. 1938. Die kultische Rolle des Zwerges im alten Ägypten. Anthropos 33: 445-514.

(C) 2020 by the author. Licensee MDPI, Basel, Switzerland. This article is an open access article distributed under the terms and conditions of the Creative Commons Attribution (CC BY) license (http://creativecommons.org/licenses/by/4.0/). 